\title{
MINERAL WATERS OF SERBIA AND DEVELOPMENT OF PHOTOTROPHIC MICROBIAL COMMUNITIES NEAR POINTS OF EMERGENCE AND ON WELLHEADS
}

\author{
MINERALNE VODE V SRBIJI IN RAZVOJ FOTOTROFNIH \\ MIKROBNIH ZDRUŽB NA MESTIH IZVIROV IN \\ NA USTJIH VRTIN
}

\author{
Vladimir ŠARABA ${ }^{1 *}$, Slađana POPOVIĆ ${ }^{2}$, Olivera KRUNIĆ ${ }^{1}$, Gordana SUBAKOV SIMIĆ ${ }^{3}$, \\ Željko KLJAJIĆ ${ }^{1} \&$ Milojko LAZIĆ ${ }^{1}$
}

\begin{abstract}
UDC 553.7:579(497.11)

Vladimir Šaraba, Slađana Popović, Olivera Krunić, Gordana Subakov Simić, Željko Kljajić, Milojko Lazić: Mineral waters of Serbia and development of phototrophic microbial communities near points of emergence and on wellheads

Phototropic microorganisms in thermal mats had not attracted enough attention in Serbia in the past. The research presented in this paper is the first to address biofilms at selected occurrences of mineral water in Serbia (Bogatić, Metković and Belotić in the Mačva District as well as Radaljska Banja, Lukovska Banja and Vranjska Banja) (in Serbian, banja denotes a spa town). The study period is from 2014 to 2016 . The temperatures of the studied occurrences are in the $30-93.9^{\circ} \mathrm{C}$ range and the chemical composition corresponds to the $\mathrm{HCO}_{3}^{-}-$ $\mathrm{Na}^{+}+\mathrm{K}^{+}$and $\mathrm{SO}_{4}^{2-}, \mathrm{HCO}_{3}^{-}-\mathrm{Na}^{+}+\mathrm{K}^{+}$types of mineral water. One of the objectives was to examine the condition of wellheads (incrustation, biofouling and corrosion), focusing on the presence of phototrophic microorganisms whose metabolites may lead to changes in mineral water quality, yield and chemistry. Analysis by light and scanning electron microscopy provides insight into the diversity of phototrophic microorganisms that populate biofilms near the points of emergence and on wellhead. The research reveals the presence of representatives of three groups of phototrophic microorganisms: Cyanobacteria, Chlorophyta and Bacillariophyta. Cyanobacteria were the most numerous, dominated by the order Oscillatoriales with ten recorded genera, of which Leptolynbgya and Phormidium feature the largest numbers of species. The order Chroococcales are the second most numerous, with seven recorded genera, of which Gloeocapsa and Synechocystisare the most noteworthy. The largest numbers of representative taxa were noted at Radaljska Banja and Vranjska Banja, where mineral waters originate from
\end{abstract}

Izvleček

UDK 553.7:579(497.11)

Vladimir Šaraba, Slađana Popović, Olivera Krunić, Gordana Subakov Simić, Željko Kljajić, Milojko Lazić: Mineralne vode $v$ Srbiji in razvoj fototrofnih mikrobnih združb na mestih izvirov in na ustjih vrtin

Fototrofni mikroorganizmi $\mathrm{v}$ oblogah termalnih izvirov $\mathrm{v}$ Srbiji v preteklosti niso bili deležni posebne pozornosti. V članku predstavljena raziskava je prva, ki obravnava biofilme na izbranih mestih izvirov mineralnih vod v Srbiji (Bogatić, Metković in Belotić v Mačvi ter Radaljska Banja, Lukovska Banja in Vranjska Banja) (v srbskem jeziku je banja izraz za toplice). Preučevanje je potekalo med letoma 2014 in 2016. Temperature obravnavanih voda se gibljejo med 30 in $93,9^{\circ} \mathrm{C}$, glede na kemijsko sestavo pa jih uvrščamo $v \mathrm{HCO}_{3}^{-}-\mathrm{Na}^{+}+\mathrm{K}^{+}$ in $\mathrm{SO}_{4}^{2-}, \mathrm{HCO}_{3}^{-}-\mathrm{Na}^{+}+\mathrm{K}^{+}$tipe mineralne vode. Eden od ciljev raziskave je bil proučevati razmere na ustjih vrtin (inkrustacija, obrast in korozija) in se še posebej posvetiti navzočnosti fototrofnih mikroorganizmov, katerih metaboliti lahko spremenijo kakovost, izdatnost in kemizem mineralnih vod. Z analizo slik s svetlobnim in vrstičnim elektronskim mikroskopom lahko podrobneje spoznamo raznolikost fototrofnih organizmov, ki sestavljajo biofilme na mestih izvirov in na ustjih vrtin. Raziskava je pokazala obstoj predstavnikov treh skupin fototrofnih mikroorganizmov: cianobakterij ter predstavnikov debel Chlorophyta in Bacillariophyta. Cianobakterije so bile najbolj številčne, prevladovali so osebki reda Oscillatoriales z desetimi ugotovljenimi rodovi, od katerih je bilo največje število vrst iz rodov Leptolynbgya in Phormidium. Red Chroococcales je bil s sedmimi zabeleženimi rodovi drugi najbolj številčen, prevladovala sta Gloeocapsa in Synechocystis. Največreprezentativnih taksonov je bilo v Radaljski Banji in Vranjski Banji, kjer mineralne vode izvirajo iz litostratigrafskih

\footnotetext{
${ }^{1}$ University of Belgrade, Faculty of Mining and Geology, Đušina 7, Belgrade, Serbia, e-mails: vladimirsaraba@ymail.com, olivera.krunic@rgf.bg.ac.rs, kljajiczeljko@yahoo.com, milojko.lazic@rgf.bg.ac.rs

${ }^{2}$ University of Belgrade, Institute of Chemistry, Technology and Metallurgy, Department of Ecology and Technoeconomics,

Karnegijeva 4, Belgrade, Serbia, e-mail: spopovic.bio@gmail.com

${ }^{3}$ University of Belgrade, Faculty of Biology, Studentski trg 16, e-mail: gsubak@bio.bg.ac.rs

${ }^{*}$ Corresponding Author
}

Received/Prejeto: 24.04.2017 
lithostratigraphic units of igneous origin, followed by mineral water occurrences in karst aquifers (Bogatić and Belotić) and an intergranular aquifer (Metković). The smallest number of identified phototrophic microorganisms is noted at Lukovska Banja, where the origin is associated with a fractured aquifer formed in sedimentary and metamorphic rocks, with occasional diabase interbeds. Although many representative taxa are found on only one of the studied localities, such as Synechococcus bigranulatus and Pseudanabaena thermalis, those of the genera Leptolyngbya, Phormidium and Cosmarium laeve, as well as genera of the phylum Bacillariophyta, occur at several sampling sites. Principal component analysis (PCA) was used to show the relationship between documented cyanobacterial and algal taxa and environmental parameters.

Key words: Serbia, mineral waters, phototrophic microorganisms, biofilm. enot vulkanskega izvora, sledijo mineralne vode iz kraškega (Bogatić in Belotić) in medzrnskega vodonosnika (Metković). Najmanjfototrofnih organizmov je bilo v vzorcu iz Lukovske Banje, kjer vode izvirajo iz razpoklinskih vodonosnikov v sedimentnih in metamorfnih kamninah $\mathrm{z}$ vmesnimi lečami diabaza. Čeprav soštevilne reprezentativne taksone našli le na eni od proučevanih lokacij, kot na primer Synechococcus bigranulatus in Pseudanabaena thermalis, se tisti iz rodu Leptolyngbya, Phormidium in Cosmarium laeve in predstavniki več rodov, ki pripadajo deblu Bacillariophyta, pojavljajo na več vzorčnih mestih. Za ugotavljanje odvisnosti med taksoni cianobakterij in alg ter okoljskimi parametri so uporabili analizo glavnih komponent.

Ključne besede: Srbija, mineralne vode, fototrofni mikroorganizmi, biofilm.

\section{INTRODUCTION}

Different geologic, chemical and other conditions make each occurrence of groundwater a unique ecosystem, which is more or less complex and where microorganisms are acclimated to the particular setting. They persist owing to special physiological and ecological adaptations and a variety of distinct properties (Griebler \& Lueders 2009).

The presence of microorganisms in groundwater and near the place of emergence is constrained by numerous factors. The impact of the $\mathrm{pH}$ level, ionic activity and temperature is unavoidable (Donlan 2002; Li \& Logan 2004). The microbial count also depends, inter alia, on the concentrations of dissolved organic and inorganic carbon, as well as other nutrients in the groundwater (Lehman 2001). In most cases, microorganisms survive as long as enough resources are available for growth and reproduction (Lawrence \& Caldwell 1987; Szewzyk \& Schink 1988).

In groundwater and near the point of emergence, microorganisms tend to build biofilms attached to the rock matrix (Hazen et al. 1991; Griebler et al. 2001). Biofilms are considered to be the earliest ecosystems on the planet Earth (Tice \& Lowe 2004; Noffke et al. 2006); they have been around for more than three billion years (Hoffman et al. 1999; Schopf 2006). Over time, they have altered the oxidation-reduction conditions on Earth (Des Marais 1995; Farmer 2000). It is believed that biofilms spearheaded the process of photosynthesis (Des Marais 2000; Kasting \& Howard 2006). Biofilm ecosystems are extremely efficient in the circulation of elements in nature (Visscher \& Stolz 2005). The photosynthetic capability, light utilization efficiency, and rate of procreation of phototrophic biofilm algae constitute some of the most powerful mechanisms that covert sunlight into organic matter. Owing to these characteristics, microalgae and cyanobacteria are extremely important in biotechnology. Biofilms are also an ideal substrate for astrobiological research (Toporski et al. 2003), given that the study of life in such extreme environments parallels that of potential life on other planets (Pedersen 2000).

At all the studied mineral water sites in Serbia, the production wells have aged. Well ageing has an adverse effect on the structural and/or hydraulic characteristics of the well screen and the aquifer matrix around the screen. It comprises all process related to the degradation of materials due to corrosion, as well as mechanical and chemical clogging of screen slots, the gravel pack and the zone of the aquifer adjacent to the screen. In nearly all cases, well ageing leads to the deterioration of hydraulic characteristics (Driscoll 1986; Houben \& Treskatis 2007). During the course of operation, wells tend to exhibit five major problems (Driscoll 1986): (i) declining capacity, due to chemical incrustation or biofouling in and around the screen, (ii) mechanical clogging - sanding caused by corrosion of the screen or well tube, (iii) electrolytic corrosion - usually where the $\mathrm{pH}$ level of the groundwater is low and $\mathrm{CO}_{2}$ concentrations high, (iv) biofouling, and (v) chemical incrustation. The main types of incrustation in Serbia are related to the precipitation of calcium and magnesium carbonates and sulfates and iron and manganese compounds, primarily their hydroxides and hydrated oxides, but also those that are a result of mechanical and chemical activity of various microorganisms. These are also the most frequent forms of incrustation in worldwide hydrogeological practice, as reported by: Driscoll 1986; Houben \& Treskatis 2007. Encrusta- 
tions of biological origin are comprised of microbial communities and mineral substances precipitated either from the groundwater or by the microorganisms themselves. The deposits are initially small, dominated by the biological component. However, over time, mineral substances acquire an increasing share and ultimately make up most of the mass. The end products tend to constitute large obstacles for groundwater flow. It is estimated that $80 \%$ of encrustations are of biological origin (Schnieders 2003).

The composition of biofilms also depends on the physical and chemical characteristics of the substrate on which they develop, the bacterial species that colonize them, and the type of material (LeChevallier et al. 1996). Different pipes in contact with water release various substances that are a source of nutrients for the microorganisms which, after they establish a community, tend to spread rather quickly. Pipes that contain polyamide and silicon can cause bacterial proliferation, as can materials that include bitumen, epoxy resin or tar-epoxy resin (Schoenen 1986). The interactions between microorganisms and materials need to be seriously considered during in the design stage of groundwater extraction and transport facilities (Beech \& Sunner 2006).

There is another important component of the study of phototrophic microbial mats near the points of emergence of mineral water and on wellheads in Serbia, given that extremophiles able to produce various secondary metabolites and other thermostable compounds have been detected. Cyanobacteria and algae often adapted to very harsh conditions. The benefits of algae have been known since ancient times, owing to their anti-inflammatory and anti-microbial properties. The importance of algae to the human population is multi-faceted: fixing of atmospheric nitrogen, creation of toxins, and primary production - organic substances and products of photosynthesis, as well as because of secondary metabolites, economic significance and bioindication (Cvijan 2013; Šaraba \& Krunić 2017).

The development of phototrophic microbial communities near the points of emergence of mineral water and on wellheads in Serbia had not previously been researched. One of the objectives of the present study was to evaluate the status of wellheads (incrustation, biofouling and corrosion that may lead to changes in water quality and yield), and to conduct chemical analyses of the mineral waters. Another objective was to assess cyanobacterial and algal diversity in thermal mats near the point of emergence and on wellheads. Also, an attempt was made to establish a correlation between documented phototrophic taxa and measured environmental parameters (physicochemical water characteristics) using multivariate analyses, as well as between the geologic environment in which the mineral waters originate (karst, fractured and intergranular aquifers) and the microbial community on the ground surface, given that groundwater acquires the properties of the rocks through which it flows. This, inter alia, has an effect on phototrophic microorganisms, along with the microclimate and other environmental factors.

\section{STUDY AREAS}

The studied occurrences of mineral waters are found in the Inner Dinarides of western Serbia - Bogatić, Metković and Belotić in the Mačva District and Radaljska Banja; in the Šumadija-Kopaonik-Kosovo province - Lukovska Banja, and the Serbian Crystalline Core - Vranjska Banja (Filipović et al. 2005), (Fig. 1). The zoning is based on tectonics, lithofacies, geomorphology, hydrogeology, and physical, geographic and other characteristics used to identify the geologic provinces of Serbia (Krunić 2012).

The studied occurrences of mineral water in the Mačva District (Bogatić, Metković and Belotić) are formed within the basin structure, in Triassic limestone, Triassic pyritized dolomite and Eocene sandstone aquifers, underlain by plutonites which, among other things, cause elevated temperatures of the mineral waters. Karst and intergranular aquifers are tapped on those loca- tions. The fractured aquifer at Radaljska Banja is found in compact and fractured polymineralic igneous rocks (granodiorites), whereas that at Lukovska Banja occurs in Cretaceous sandy, oolitic, stratified, banked and massive limestones, with serpentinite, diabase-chert, sandstone, marl, conglomerate and mudstone components. At Vranjska Banja, mineral water is captured from a matrix of metamorphic and igneous rocks: micaschists, leptinolites, gneisses, gneiss-granites and a volcanic sedimentary complex, represented by Neogene volcanic dust, sand and ash (Filipović et al. 2005). The studied mineral waters are tapped from different geologic media, including karst (Bogatić, Belotić and Lukovska Banja), fractured (Radaljska Banja and Vranjska Banja) and intergranular (Metković) aquifers, whose hydrodynamic characteristics differ. Some of the aquifers are unconfined, while others are confined. 


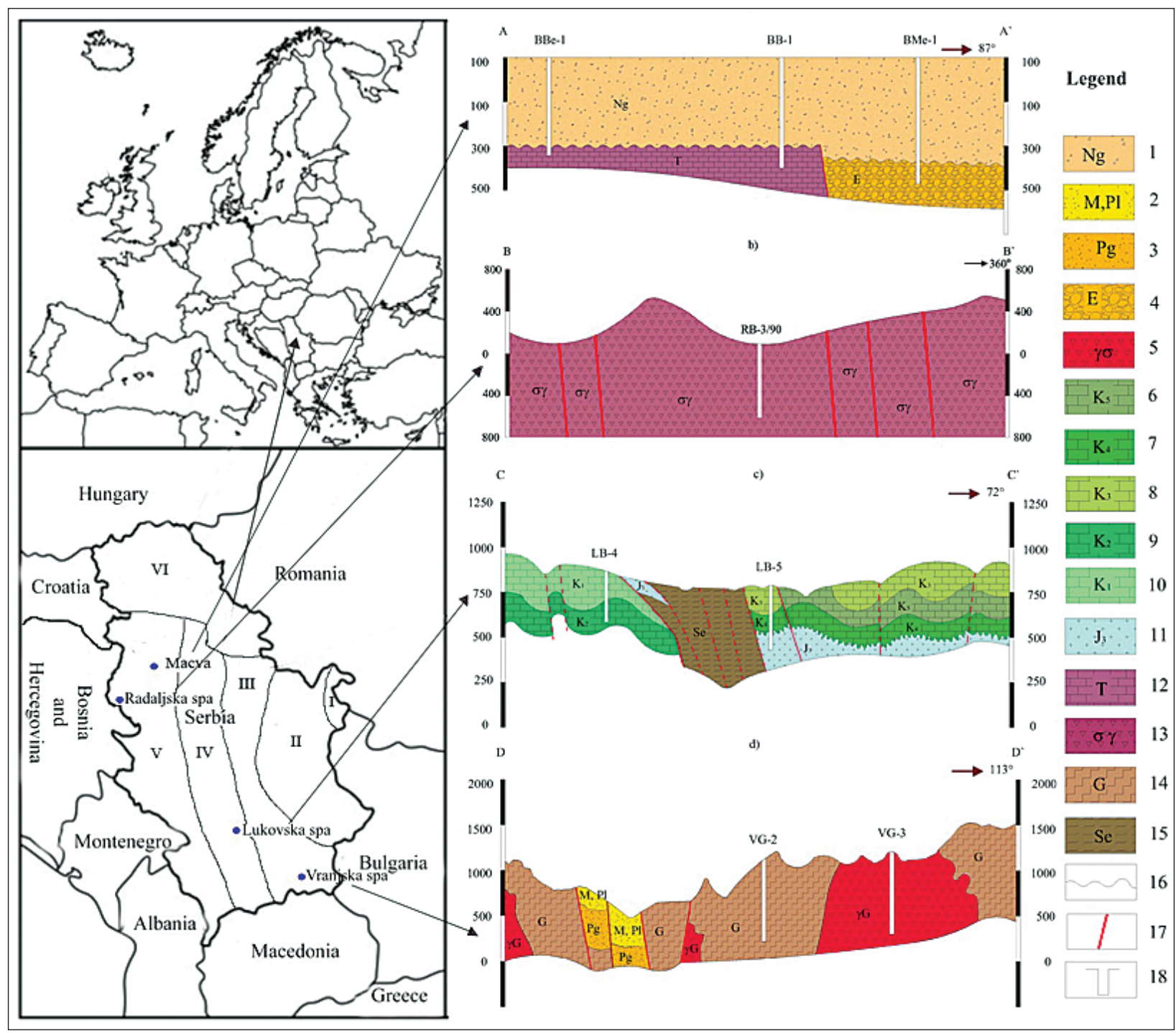

Fig. 1: Schematic representation of the geographic and geotectonic positions and geologic microlocation frameworks of the studied occurrences of mineral waters in Serbia.

Legend: I - Dacian Basin; II - Carpathian-Balkanide province; III - Serbian Crystalline Core; IV - Šumadija-Kopaonik-Kosovo province; V - Inner Dinarides of western Serbia; VI - Pannonian Plain; a) Geological section at Bogatić (BB-1), Metković (BMe-1)and Belotić (BBe-1) -Mačva region; b) Geological section at Radaljska Banja (RB-3/90); c) Geological section at Lukovska Banja (LB-4 and LB-5); d) Geological section at Vranjska Banja (VG-2 and VG-3); 1 - Neogene sediments: coarse gravel, marly clay, sand, clay, sandstone, conglomerate; 2 - Igneous sedimentary complex; 3 - Tuff; 4 - Eocene sandstone; 5 - Granite; 6 - Limestone, marly limestone, slate and sandstone; 7 - Limestone, marl and sandstone; 8 - Limestone, coarse banked sandstone, marl, conglomerate, siltstone; 9 - Limestone, siltstone, sandstone, marl; 10 - Limestone, sandstone, conglomerate, siltstone; 11 - Diabase-chert formation: sandstone, limestone, chert and slate; 12 - Triassic limestone; 13 - Granodiorites and granodiorite-porphyritic rocks; 14 - Gneiss, micaschist and leptinolites; 15 - Serpentinite; 16 - Geological boundary; 17 - Fault; 18 - Well.

From a tectonic perspective, the Mačva District is a wing of the large Sava trench, between Mt. Cer and Mt. Fruška Gora, where a regional fault trending west-east runs along the valley of the Sava River. The trench was formed in several stages, ending with the Pleistocene. Radaljska Banja belongs to the large Drina anticline, cross-crossed by primary fault structures and a series of lower-order faults, perpendicular to each other. They play a significant role in the formation of mineral water on this locality. The boundaries are clearly dominated by a fault zone, intersected by subsequent lateral faulting. Vranjska Banja is part of the Vranje trench and the occurrences of mineral water are associated with a folding zone, where in relative terms the block south and south- 
west of Vranjska Banja rises and the central part sinks. The tectonic complexity of Lukovska Banja is attributed to the fact that mineral water occurs at the very contact between large regional tectonic units of the western "External Vardar Sub-zone" and the eastern "Central Vardar Sub-zone". In general, the terrain was created in several stages, which led to considerable vertical and horizontal displacements. The first resulted in uplifting of the central part of the terrain and deposition of Cretaceous sediments along the western and eastern edges. In the Upper Cretaceous, there was intensive tectonic movement that created the Central Vardar Sub-zone". Uplifting of the Jurassic and Jurassic-Cretaceous complex and the central and eastern tectonic units continued. Strong
post-Senonian tectonic movements resulted in considerable horizontal and vertical displacement of the blocks, particularly in the central zone of the studied site, as well as folding of the Cretaceous complex in the eastern and western parts, which drove the formation and emergence of mineral water (Filipović et al. 2005; Krunić 2012). All of the above have impeded the determination of hydrogeologic structures and mineral water flow rates, which have not been accurately established to date.

Vertical sections through the geologic framework of the areas where mineral waters emerge and are tapped are shown in Figure 1; the relevant zones are identified by blue dots in the lower left corner.

\section{MATERIALS AND METHODS}

Detailed geological investigations began with a review of available documentation pertaining to several decades of regional hydrogeological exploration, including information about previous physical and chemical testing of mineral water and the geologic framework within the zones of emergence of mineral water (Fig. 1). The review was followed by hydrogeological reconnaissance of the study areas. The occurrences and wells were identified and then sampling conducted accordingly. Given the topic and objectives of the research, the materials and methods related to geologic exploration included sampling of: (i) mineral waters, along with physical and chemical analyses, and (ii) encrustations.

The biological stage of the research focused on proper sampling of the phototropic biofilms, which had been formed over time on the wellhead and near the point of emergence of mineral water, followed by light and scanning electron microscopy and identification of microorganisms.

These steps of the research allowed for symbiosis of biological and geologic facts.

\section{SITE DESCRIPTION AND SAMPLING}

The present paper is an outcome of previous multiyear regional hydrogeological exploration of mineral waters in Serbia as well as specially designed investigations conducted from 2014 to 2016.

Mineral water is groundwater whose temperature is above $20^{\circ} \mathrm{C}$, total dissolved solids (TDS) greater than $1 \mathrm{~g} / \mathrm{l}$, and/or that which contains elevated concentrations of certain chemical components (macro and micro), features elevated radioactivity, and includes free and dissolved gases, biologically active components, and the like, whose properties constitute a special class of groundwater (Krunić 2012).

The mineral water occurrences in Serbia were selected either because of their significance in terms of use (Radaljska Banja, Lukovska Banja and Vranjska Banja - balneotourism) or their potential and physical properties such as in the Mačva District (Bogatić, Metković and Belotić).The selection was also influenced by practical reasons: for example Bogatić (need to rehabilitate well BB-1), and the fact that one of the objectives was to investigate areas of different structural geology, lithofacies, hydrogeology and other characteristics, as well as mineral water occurrences of different temperatures.

In the past, mineral water occurrences had been addressed from the viewpoint of geologic framework, characteristic rock complexes in which they are found, basic ionic and gas compositions, specific components, likely primary origin, fundamental and specific processes that lead to the formation of the chemical composition, regime, reserves, and potential for multi-purpose use (Krunić et al. 2016). The development of phototrophic organisms in biofilms near the points of emergence of mineral water and on wellheads has not previously been studied in Serbia.

It should be noted that past hydrogeological exploration had often been affected by microbial activity at the wells and near the points of emergence of groundwater, but no appropriate biological research was undertaken.

One of the significant aspects of the research conducted from 2014 to 2016 was the identification of phototrophic microorganisms on wellheads, which, among other things, led in well ageing. 
Tab. 1: Characteristics of studied occurrences of mineral waters (Martinović \& Milivojević 1998; Krunić 1999; Filipović 2003; Filipović et al. 2005; Krunić 2012; Martinović et al. 2012).

\begin{tabular}{|c|c|c|c|c|c|}
\hline Locality & Well & Depth of well $(m)$ & Lithology & Yield $(I / s)$ & Type of mineral water \\
\hline Bogatić & BB-1 & 470 & Triassic limestone & 37.5 & $\mathrm{HCO}_{3}-\mathrm{Na}+\mathrm{K}$ \\
\hline Metković & BMe-1 & 370 & $\begin{array}{l}\text { Neogene sandstone from quartz } \\
\text { minerals with lime binder }\end{array}$ & 15 & $\mathrm{HCO}_{3}-\mathrm{Na}+\mathrm{K}$ \\
\hline Belotić & BBe-1 & 627 & Triassic dolomite, pyritized & 10 & $\mathrm{HCO}_{3}-\mathrm{Na}+\mathrm{K}$ \\
\hline Radaljska Banja & $\mathrm{RB}-3 / 90$ & 366 & $\begin{array}{l}\text { Compact and fractured } \\
\text { granodiorite }\end{array}$ & 3 & $\mathrm{HCO}_{3}-\mathrm{Na}+\mathrm{K}$ \\
\hline \multirow{2}{*}{ Lukovska Banja } & LB-4 & 401 & Cretaceous limestone & 4.7 & $\mathrm{HCO}_{3}-\mathrm{Na}+\mathrm{K}$ \\
\hline & LB-5 & 870 & Cretaceous limestone & 4.6 & $\mathrm{HCO}_{3}-\mathrm{Na}+\mathrm{K}$ \\
\hline \multirow{2}{*}{ Vranjska Banja } & VG-2 & 1064 & $\begin{array}{l}\text { Petrified granodiorite and gneiss- } \\
\text { granite, amphibole-biotite schist }\end{array}$ & 26 & $\mathrm{SO}_{4^{\prime}} \mathrm{HCO}_{3}-\mathrm{Na}+\mathrm{K}$ \\
\hline & VG-3 & 1470 & $\begin{array}{l}\text { Petrified quartz-diorite, grandiorite, } \\
\text { with schist intercalations }\end{array}$ & 21 & $\mathrm{SO}_{4^{\prime}} \mathrm{HCO}_{3}-\mathrm{Na}+\mathrm{K}$ \\
\hline
\end{tabular}

The mineral water sampling points were near mineral water emergences and on wellheads (Fig. 2). The points of emergence (or discharge) of mineral water are places where mineral water reaches the ground surface via a free-flowing well or well whose column leaks due to ageing or drained naturally (Dragišić \& Polomčić 2009), whereas the wellhead is the place on the ground surface where the extraction well begins (Lazić 2003).

The characteristics of the studied mineral waters are shown in Tab. 1.

Mineral waters were sampled for chemical and physicochemical analyses at eight locations (Bogatić well BB-1; Metković - well BMe-1; Belotić - well BBe-1; Radaljska Banja - well RB 3/90; Lukovska Banja - wells LB-4 and LB-5; and Vranjska Banja - wells VG-2 and VG-3). Contrary to sampling of mineral waters for chemical analyses, the discharge zones of the wells at Lukovska Banja (wells LB-4 and LB-5) and Vranjska Banja (wells VG-2 and VG-3) were close together and covered by the same type of biofilm, such that sampling for microbiological analyses was undertaken simultaneously at both wells in Lukovska Banja and Vranjska Banja. A total of six discharge zones were sampled for microbiological analyses.

Sampling of mineral waters and biofilms was conducted over a two-year period, from 2014 to 2016. At Bogatić, Metković and Belotić, samples were collected in mid-December 2014 - when autumn ended and winter began, and on the other locations (Radaljska Banja, Lukovska Banja and Vranjska Banja) in April and May 2015.

\section{PHYSICAL AND CHEMICAL ANALYSES OF MINERAL WATERS}

Samples of mineral water for physical and chemical analyses were collected in plastic bottles. The bottles were sterile and the caps complied with international standards ISO 9001, ISO 14001 and OHSAS 18001. Prior to use, the bottles were rinsed and cleaned with a $1 \% \mathrm{HCl}$ solution, then flushed with distilled water. Upon sampling of mineral water, the bottles were capped to prevent leakage and then sealed with a nut. The bottles were labeled, indicating serial numbers and other important information, like the name of the sampling site, water temperature $(\mathrm{T}), \mathrm{pH}$, and total dissolved solids (TDS). Mineral water samples for physicochemical analyses and biofilm samples for microbiological analyses were collected at the same time. The temperature (T), $\mathrm{pH}$ and conductivity (EC) of the mineral waters were determined in situ (Tab. 2).

CyberScan CON $510 \mathrm{pH}$ meter was used to determine $\mathrm{pH}$ levels and temperatures. This instrument could also be used to measure total dissolved solids (TDS). Conductometer HI98192 was used to measure conductivity. This instrument is equipped with a four-ring HI763133 conductivity electrode.

The other parameters were analyzed in the laboratory for physical and chemical analyses of Belgrade's Public Health Institute (TDS, $\mathrm{Na}^{+}+\mathrm{K}^{+}, \mathrm{Ca}^{2+}, \mathrm{Mg}^{2+}, \mathrm{Cl}^{-}$, $\left.\mathrm{SO}_{4}^{2-}, \mathrm{NO}_{2}^{-}, \mathrm{NO}_{3}^{-}, \mathrm{NH}_{4}^{+}\right)(\mathrm{Tab} .2)$.

\section{MICROSCOPIC EXAMINATIONS}

The microbial mat samples were analyzed using light and electron microscopy (SEM-EDS analysis) at the laboratories of the University of Belgrade/Faculty of Biology and Faculty of Mining and Geology.

Algological analyses. Mat samples were collected near the points of emergence of mineral water and at wellheads in Bogatić, Metković, Belotić, Radaljska Banja, Lukovska Banja and Vranjska Banja (Fig. 2). Sampling sites with notable highly-developed and variously colored biofilm were chosen for analysis. The samples were collected using a sterilized scalpel, placed in sterile plastic bottles and fixed with a $1.5 \%$ formaldehyde solution. The samples were analyzed using a light microscope (Zeiss Axio Imager-M1 with AxioVision 4.8 soft- 

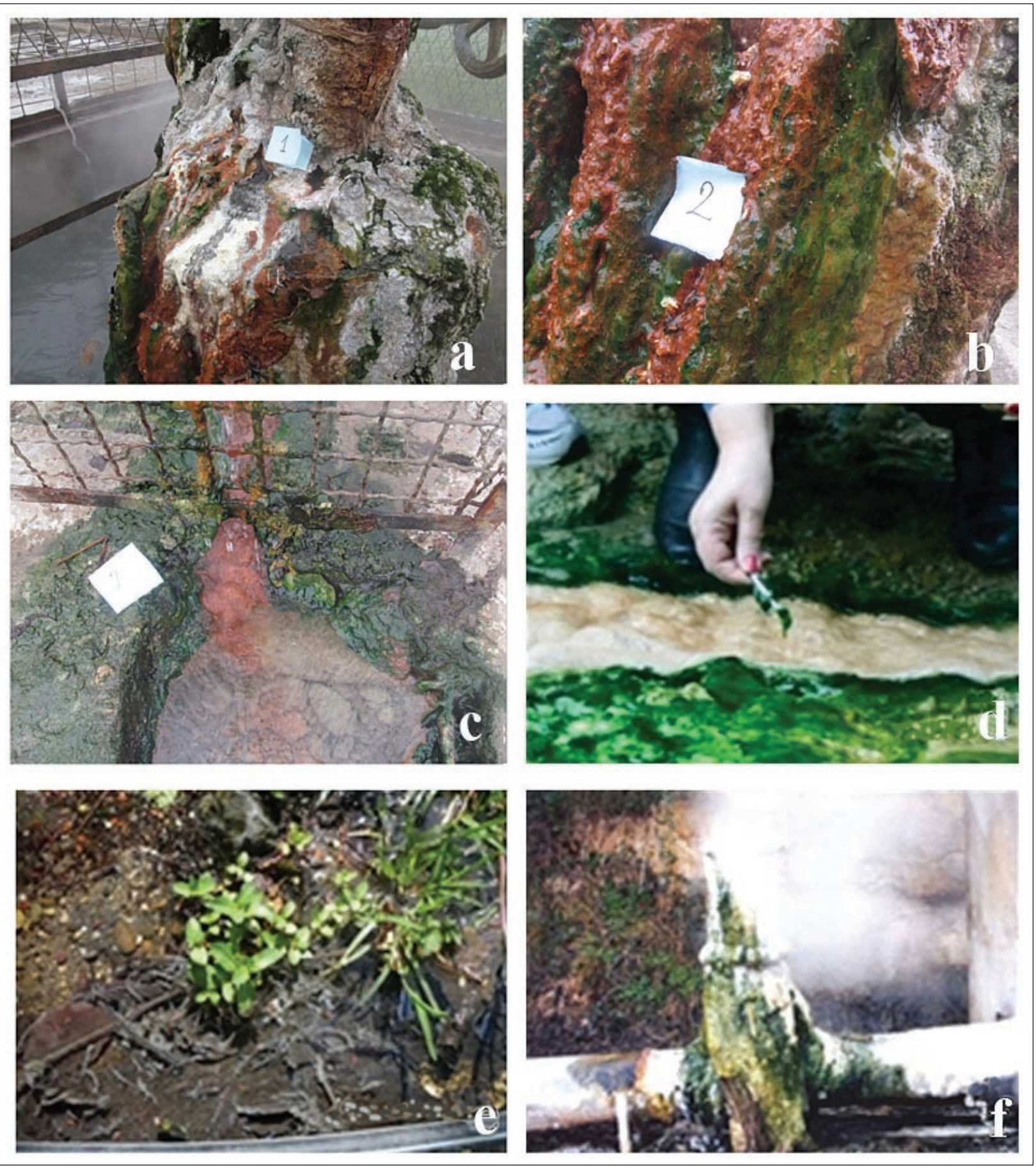

Fig. 2: Biofilm sampling sites for microbiological analyses of mineral waters in Serbia (Photo: M. Lazić, 2014-2016).

Legend: a) Bogatić; b) Metković; c) Belotić; d) Lukovska Banja; e) Radaljska Banja;f) Vranjska Banja.

ware) and the cyanobacteria and algae were identified according to: Krieger \& Gerloff 1965; Komárek \& Fott 1983; Komárek \& Anagnostidis 1998, 2005; Komárek 2013; Komárek et al. 2014; Lange-Bertalot et al. 2011; Hofmann et al. 2013. Despite using a new technique, the cultivation of these thermal microorganisms was not successful. It is well-known that cyanobacteria from extreme environments, especially coccoid taxa, are generally hard to cultivate, since the imitation of their original habitats is usually an obstacle. For that reason, our study involved only one-time screening of cyanobacterial and algal taxa. 
SEM-EDS analyses. These analyses were conducted using an electron microscope. Phase compositions of powdered black crust and powdered dry residue were determined by X-ray powder diffraction (XRPD). XRPD was performed on a Philips PW1710 diffractometer. The diffraction patterns were obtained from 5 to $70^{\circ} 2 \theta$, with a step scan of $0.02^{\circ} 2 \theta$ and $0.5 \mathrm{~s}$ of counting time at each step using $\mathrm{CuK}$ a radiation. The morphology and chemical composition of the mineral phases present in the dry residue of water were identified using a JEOL JSM-6610LV Scanning Electron Microscope connected to an XMax Energy Dispersive Spectrometer. The samples were coated with gold using a BALTECSCD-005 SPUTTER coating device and recorded under high vacuum conditions.

\section{STATISTICAL ANALYSES}

Principal component analysis (PCA) was performed using the program CANOCO for Windows, Version 5.0 (Ter Braak \& Šmilauer 2012). PCA was applied to examine the relationship between documented cyanobacterial and algal taxa and measured environmental variables. For project data, the presence/absence of all recorded taxa was used as a measure. Then, each taxon was assigned to a taxonomic group (Chroococcales, Oscillatoriales and Nostocales (the three corresponding to Cyanobacteria), Chlorophyta and Bacillariophyta). In further analysis, these formed groups were used instead of individual taxa. Measured environmental parameters (physical and chemical water parameters), as well as locations, were used as supplementary variables. PCA with the option "center and standardize" was applied.

\section{RESULTS AND DISCUSSION}

The results of the physical and chemical analyses (Tab. 2) indicated that the types of mineral water were $\mathrm{HCO}_{3}^{-}-$ $\mathrm{Na}^{+}+\mathrm{K}^{+}$and $\mathrm{SO}_{4}^{2-}, \mathrm{HCO}_{3}^{-}-\mathrm{Na}^{+}+\mathrm{K}^{+}$(Fig. 3, Fig. 4). The concentrations of $\mathrm{HCO}_{3}$ - ranged from $80 \mathrm{mg} / \mathrm{l}$ (well RB-3/90 at Radaljska Banja) to $5980 \mathrm{mg} / \mathrm{l}$ (well VG-3 at Vranjska Banja). Sulfate ions $\left(\mathrm{SO}_{4}^{2-}\right)$ were detected in concentrations from $2.5 \mathrm{mg} / \mathrm{l}$ (well BMe-1 at Metković) to $548.7 \mathrm{mg} / \mathrm{l}$ (well VG-2 at Vranjska Banja). Sodium $\left(\mathrm{Na}^{+}\right)$ was measured from $50 \mathrm{mg} / \mathrm{l}$ (well RB-3/90 at Radaljska Banja) to 358.0 mg/l (well VG-2 at Vranjska Banja).

The lowest temperature was recorded in well RB$3 / 90$ at Radaljska Banja $-30{ }^{\circ} \mathrm{C}$, and the highest in well VG-2 at Vranjska Banja $-93.9^{\circ} \mathrm{C}$. The $\mathrm{pH}$ level varied from 6.6 in well LB-5 at Lukovska Banja to 9.3 in well RB$3 / 90$ at Radaljska Banja. A noteworthy finding was TDS whose values varied over a broad range, from $175 \mathrm{mg} / \mathrm{l}$ in well RB-3/90 at Radaljska Banja to $1267 \mathrm{mg} / \mathrm{l}$ in well LB-4 at Lukovska Banja, as well as EC from $230 \mu \mathrm{S} / \mathrm{cm}$ at well RB-3/90 in Radaljska Banja to $1588 \mu \mathrm{S} / \mathrm{cm}$ at well LB-5 in Lukovska Banja.

Gas analyses included carbon dioxide $\left(\mathrm{CO}_{2}\right)$, oxygen $\left(\mathrm{O}_{2}\right)$ and hydrogen sulfide $\left(\mathrm{H}_{2} \mathrm{~S}\right)$. There was also a notable presence of nitrates $\left(\mathrm{NO}_{3}^{-}\right)$, measuring $5.3 \mathrm{mg} / \mathrm{l}$ at well VG-3 in Vranjska Banja, and of ammonium ions $\left(\mathrm{NH}_{4}^{+}\right)-4.92 \mathrm{mg} / \mathrm{l}$ at well BMe-1 in Metković.

Conductivity, as an electrical property of the studied mineral waters, directly correlates with the ion content and water temperature. The correlation between these physicochemical parameters is illustrated in Fig. 5.

The identified cyanobacterial and algal taxa from mat samples collected at the points of emergence of min- eral waters are listed in Tab. 3, and some representatives are shown in Figs. 6 and 7

The analyzed microbial mats near the points of emergence of mineral water and on wellheads in Bogatić, Metković, Belotić, Lukovska Banja, Radaljska Banja and Vranjska Banja (Tab. 3) revealed the presence of cyanobacteria and algae from two groups: Chlorophyta and Bacillariophyta. Taking into account the number of taxa, cyanobacteria were dominant. Many taxa were found at only one sampling site, like Chroococcus thermalis (Fig. 7b) in Vranjska Banja or Spirulina major (Fig. 7e) in Lukovska Banja. The majority of the taxa represented filamentous forms from the Oscillatoriales group (ten taxa), of which Leptolynbgya and Phormidium had the highest numbers of recorded species. Seven genera were identified in the Chroococcales group and the most frequent were Gloeocapsa and Synechocystis. Heterocytous Cyanobacteria, which belong to the Nostocales group, had only one representative of the genus Calothrix. The largest number of cyanobacterial taxa was found in the mat samples from Lukovska Banja and Vranjska Banja. The group Oscillatoriales was dominant in Radaljska Banja, Lukovska Banja and Belotić, while Chroococcales prevailed in Vranjska Banja. The diversity was also high in Belotić, where heterocystous cyanobacteria were also recorded. However, some taxa were detected at more than one site, such as Synechococcus bigranulatus, Pseudanabaena thermalis, representatives of the genera Leptolyngbya and Phormidium, Cosmarium leave, as well as members of the Bacillariophyta division. 
MINERAL WATERS OF SERBIA AND DEVELOPMENT OF PHOTOTROPHIC MICROBIAL COMMUNITIES NEAR POINTS OF ...

Tab. 2: Results of physical and chemical analyses of studied occurrences of mineral water (Public Health Institute of Belgrade, 2015).

\begin{tabular}{|c|c|c|c|c|c|c|c|c|}
\hline Parameter & $B B-1$ & $B M e-1$ & $B B e-1$ & $R B-3 / 90$ & $L B-4$ & $L B-5$ & VG-2 & VG-3 \\
\hline $\mathrm{T}\left({ }^{\circ} \mathrm{C}\right)$ & 65.9 & 59.8 & 35.0 & 30.0 & 68.1 & 62 & 93.9 & 91.2 \\
\hline TDS (mg/l) & 600 & 1082 & 850 & 175 & 1267 & 1058 & 1213 & 1145 \\
\hline $\mathrm{pH}$ & 6.9 & 7.0 & 7.2 & 9.3 & 7.5 & 6.6 & 7.9 & 8.0 \\
\hline $\mathrm{T}$ (NTU) & / & 1 & 1 & 1 & / & 14.9 & 0.6 & 0.8 \\
\hline $\mathrm{KMnO}_{4}$ demand $(\mathrm{mg} / \mathrm{l})$ & 6.9 & 9.2 & 8.7 & 1.7 & 2.2 & 3.2 & 5.5 & 4.2 \\
\hline Color (PT-Co scale) & / & / & 1 & 0 & / & 25 & $<5$ & $<5$ \\
\hline $\mathrm{EC}(\mu \mathrm{S} / \mathrm{cm})$ & 800 & 1443 & 1133 & 230 & 1513 & 1588 & 1584 & 1707 \\
\hline \multicolumn{9}{|c|}{ MACROCOMPONENTS(mg/l) } \\
\hline $\mathrm{Na}^{+}$ & 144.0 & 251.6 & 158.0 & 50.0 & 309.6 & 166 & 358.0 & 346.4 \\
\hline $\mathrm{K}^{+}$ & 13.0 & 19.8 & 13.9 & 0.7 & 23.6 & 18.6 & 19.4 & 18.4 \\
\hline $\mathrm{Ca}^{2+}$ & 33.5 & 34.7 & 47.7 & 2.2 & 41.6 & 83.2 & 12.8 & 16.0 \\
\hline $\mathrm{Mg}^{2+}$ & 6.6 & 7.8 & 10.6 & 0.07 & 17.1 & 32 & $<1.0$ & $<1.0$ \\
\hline $\mathrm{HCO}_{3}^{-}$ & 361.6 & 640.0 & 470.0 & 80 & 961.0 & 961.0 & 589.0 & 5980.0 \\
\hline $\mathrm{SO}_{4}^{2-}$ & 7.5 & 2.5 & 3.0 & 12 & 91.3 & 50.3 & 548.7 & 487.0 \\
\hline $\mathrm{Cl}^{-}$ & 103.4 & 112.7 & 106.8 & 5 & 82.0 & 46.0 & 64.0 & 60.0 \\
\hline
\end{tabular}

MICROCOMPONENTS (mg/l)

\begin{tabular}{l|l|l|l|l|l|l|l|l}
\hline $\mathrm{Pb}$ & $<0.003$ & $<0.003$ & $<0.003$ & $<0.001$ & $/$ & 0.04 & $<0.01$ & $<0.01$ \\
\hline $\mathrm{Ni}$ & $/$ & $/$ & $/$ & $/$ & $/$ & 0.11 & $<0.01$ & $<0.01$ \\
\hline $\mathrm{Ag}$ & $/$ & $/$ & $/$ & $/$ & $/$ & $<0.013$ & $/$ & $/$ \\
\hline $\mathrm{Cd}$ & $/$ & $/$ & $/$ & $<0.001$ & $/$ & $/$ & $<0.02$ & $<0.02$ \\
\hline $\mathrm{Hg}$ & $/$ & $/$ & $/$ & $<0.0002$ & $/$ & $/$ & $<0.001$ & $<0.001$ \\
\hline $\mathrm{As}$ & 0.002 & 0.002 & 0.002 & $<0.001$ & $/$ & 0.689 & $<0.01$ & $<0.01$ \\
\hline $\mathrm{Zn}$ & 0.002 & 0.002 & 0.004 & 0.002 & $/$ & $<0.014$ & $<0.02$ & $<0.02$ \\
\hline Free $\mathrm{CO}_{2}$ & 50.5 & 96.8 & 13.02 & $<0.5$ & $/$ & $/$ & 184.6 & 194.2 \\
\hline Dissolved $\mathrm{O}_{2}$ & 0.5 & 2.5 & 0.5 & 1.6 & $/$ & $/$ & 4.5 & 3.7 \\
\hline Free $\mathrm{H}_{2} \mathrm{~S}$ & 2.5 & 0.8 & 0.6 & 2.1 & $/$ & $<0.06$ & 0.008 & 0.006 \\
\hline $\mathrm{NO}_{3}^{-}$ & 0.3 & $<0.02$ & $<0.2$ & $<0.2$ & 0.7 & 0.5 & 2.3 & 5.3 \\
\hline $\mathrm{NO}_{2}^{-}$ & 0.002 & 0.003 & 0.003 & $<0.005$ & 0.005 & $<0.005$ & $<0.02$ & $<0.02$ \\
\hline $\mathrm{NH}_{4}^{+}$ & 1.80 & 4.92 & 2.46 & $<0.05$ & 1.05 & 0.75 & 0.31 & 0.32 \\
\hline
\end{tabular}

Legend: BB-1 - well in Bogatić; BMe-1 - well in Metković; BBe-1 - well in Belotić; RB-3/90 - well in Radaljska Banja; LB-4 - well in Lukovska Banja; LB-5 - well in Lukovska Banja; VG-2 - well in Vranjska Banja;VG-3 - well in Vranjska Banja; / -parameter not determined.

The largest number of recorded taxa were found in fractured aquifers within rocks of igneous origin (Radaljska Banja and Vranjska Banja), followed by karst aquifers in limestones and dolomites (Bogatić and Belotić), and the intergranular aquifer at Metković. The mineral water from the fractured aquifer within rocks of sedimentary and metamorphic origin, with diabase interbeds (Lukovska Banja), featured the lowest number of phototrophic microbial taxa.
The wellhead material was also examined in the geological research phase. Steel wellheads at the studied sites favored the development of biofilm. This has been corroborated by other researchers, who report that biofilms develop more rapidly on steel than polyvinyl chloride (PVC) (Norton \& LeChevallier 2000; Beech \& Sunner 2006). The biodiversity at wellheads was assessed at Bogatić, Metković, Belotić and Vranjska Banja, as part of the biological research phase. 


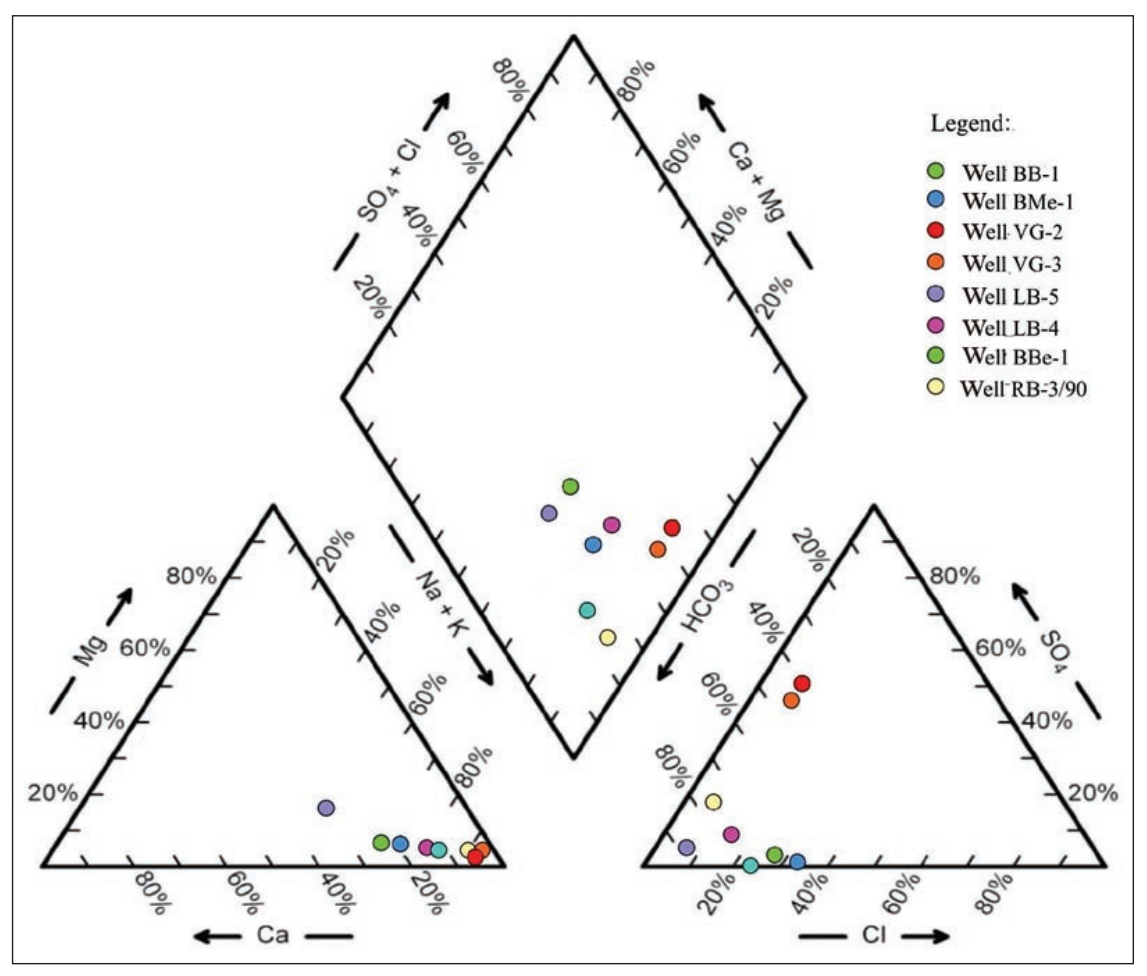

Fig. 3: Piper diagram of the chemical composition of mineral waters in Serbia.

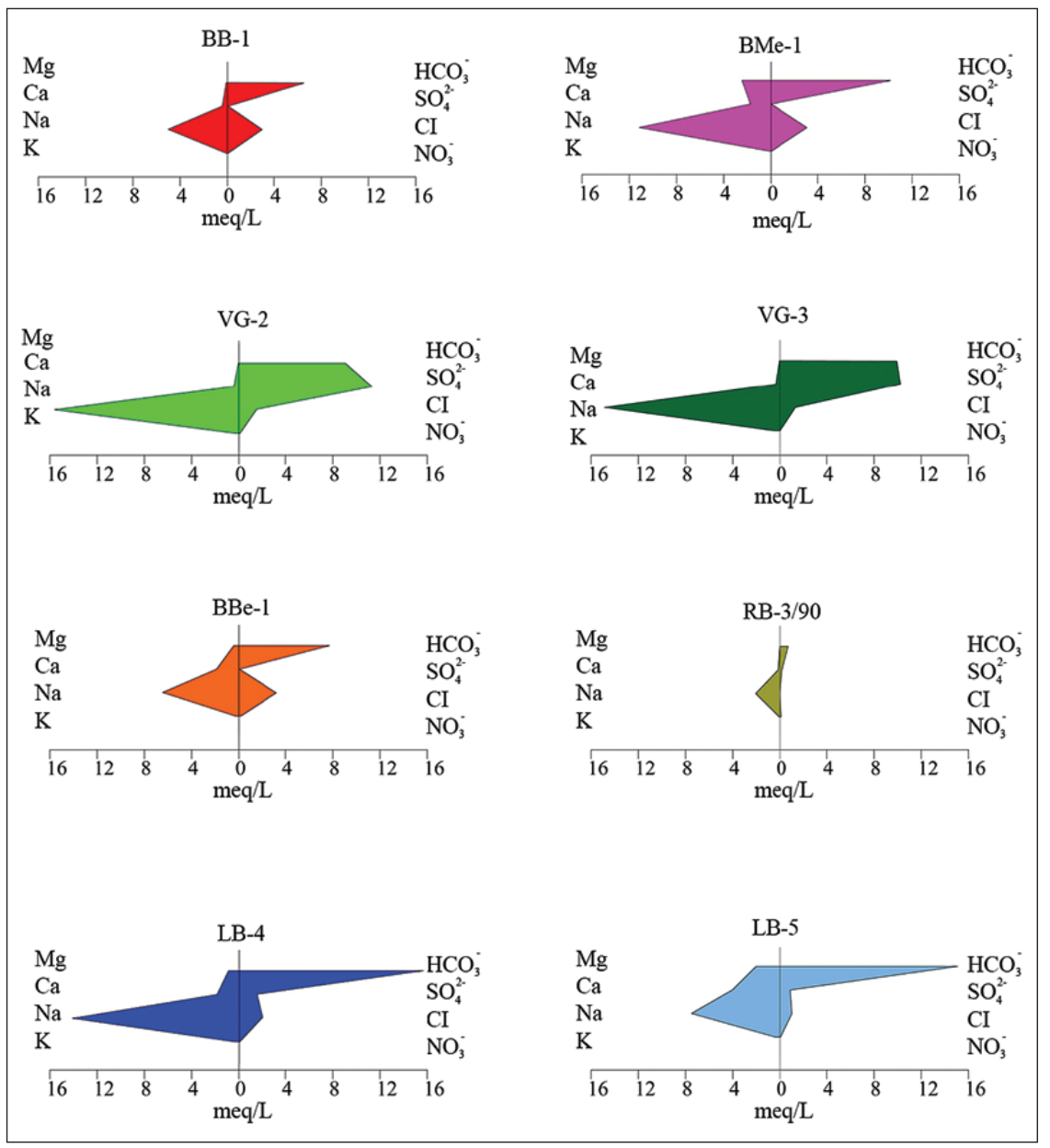

Fig. 4: Stiff diagram of the chemical composition of mineral waters: Bogatić (BB-1), Metković (BMe-1), Belotić (BBe-1), Radaljska Banja (RB3/90), Lukovska Banja (LB-4, LB-5) and Vranjska Banja (VG-2, VG-3). 
Tab. 3: Identified cyanobacterial and algal taxa.

\begin{tabular}{|c|c|c|c|c|c|c|}
\hline Identified phototrophic microorganisms & 1 & 2 & 3 & 4 & 5 & 6 \\
\hline \multicolumn{7}{|l|}{ Cyanobacteria } \\
\hline \multicolumn{7}{|l|}{ Chroococcales } \\
\hline Aphanocapsa cf thermalis (Brügger) & & & & & & + \\
\hline Aphanothece sp. (C. Nägeli) & & & & & & + \\
\hline Chroococcus thermalis (Meneghini \& Nägeli) & & & & & & + \\
\hline Cyanosarcina thermalis (Hindák \& Kovácik) & & + & & & & \\
\hline Gloeocapsa arenaria (Hassall \& Rabenhorst) & + & & + & + & & + \\
\hline Gloeocapsa gelatinosa (Kützing) & + & + & & + & & \\
\hline Synechococcus bigranulatus (Skuja) & & & & + & & + \\
\hline Synechocystis thermalis (J. J. Copeland) & & + & & & & \\
\hline Synechocystis sp. (C. Sauvageau) & & & & + & & \\
\hline \multicolumn{7}{|l|}{ Oscillatoriales } \\
\hline Borzia trilocularis (Cohn ex Gomont) & & & + & & & \\
\hline Geitlerinema amphibium (C. Agardh ex Gomont \& Anagnostidis) & & & & + & & \\
\hline Geitlerinema thermale (Anagnostidis) & & & + & & & \\
\hline Jaaginema angustissimum (West, G. S. West, Anagnostidis \& Komárek) & & + & & & & \\
\hline Jaaginema geminatum (Schwabe ex Gomont, Anagnostidis \&Komárek) & & & & + & & \\
\hline Komvophoron jovis (J. J. Copeland, Anagnostidis \& Komárek) & & + & & & & \\
\hline Leptolynggbya angustissima (West \& G. S. West, Anagnostidis \& Komárek) & & + & & & & \\
\hline Leptolyngbya foveolarum (Gomont, Anagnostidis \& Komárek) & & & & & + & + \\
\hline Leptolyngbya granulifera (J. J. Copeland \& Anagnostidis) & & & & & + & + \\
\hline Leptolyngbya laminose (Gomont ex Gomont, Anagnostidis \& Komárek) & & & & + & + & + \\
\hline Leptolyngbya orientalis (G. S. West, Anagnostidis \& Komárek) & + & + & & & & \\
\hline Leptolyngbya thermalis (Anagnostidis) & & & & & & + \\
\hline Leptolyngbya spp. (Anagnostidis \& Komárek) & & & & + & + & + \\
\hline Microcoleus chthonoplastes (Thuret ex Gomont) & & + & & & & \\
\hline Oscillatoria princeps (Vaucher ex Gomont) & & & + & + & & \\
\hline Phormidium spp. (Kützing ex Gomont) & + & & + & + & & + \\
\hline Phormidium grunowianum (Gomont, Anagnostidis \& Komárek) & & & + & + & & \\
\hline Phormidium jasorvense (Vouk, Anagnostidis \& Komárek) & + & & & & & \\
\hline Phormidium terebriforme (C. Agardh ex Gomont, Anagnostidis \& Komárek) & + & & & & & \\
\hline Phormidium tergestinum (Rabenhorst ex Gomont) Anagnostidis \& Komárek) & & & + & & & \\
\hline Pseudanabaena thermalis (Anagnostidis) & + & & & + & + & + \\
\hline Spirulina major (Kützing ex Gomont) & & & & + & & \\
\hline \multicolumn{7}{|l|}{ Nostocales } \\
\hline Calotxrix thermalis (Hasngirg ex Bornet \& Flahault) & & & + & & & \\
\hline \multicolumn{7}{|l|}{ Chlorophyta } \\
\hline Cosmarium laeve (Rabenhorst) & + & & + & & + & \\
\hline \multicolumn{7}{|l|}{ Bacillariophyta } \\
\hline Epithemia sp. (Kützing) & & & & + & & \\
\hline Navicula spp. (Bory) & + & + & + & + & + & \\
\hline Nitzschia spp. (Hassall) & + & & & & + & \\
\hline
\end{tabular}

Legend: 1 - well BB-1 (Bogatić); 2 - well BMe-1 (Metković); 3 - well BBe-1(Belotić); 4 - well RB-3/90 (Radaljska Banja); 5 - wells LB-4 and LB-5 (Lukovska Banja); 6 - wells VG-2 and VG-3 (Vranjska Banja).

Along with other environmental factors, microclimate conditions affect the development of thermal biofilms.

The climate in the Mačva District (Bogatić, Metković and Belotić) and Radaljska Banja is moderately continental, while that at Lukovska Banja and Vranjska Banja is moderately continental but modified by the influence of mountainous climate (Filipović et al. 2005).

The perennial average precipitation (Pav) and air temperature $(\mathrm{T})$ in the study areas were: Bogatić, 


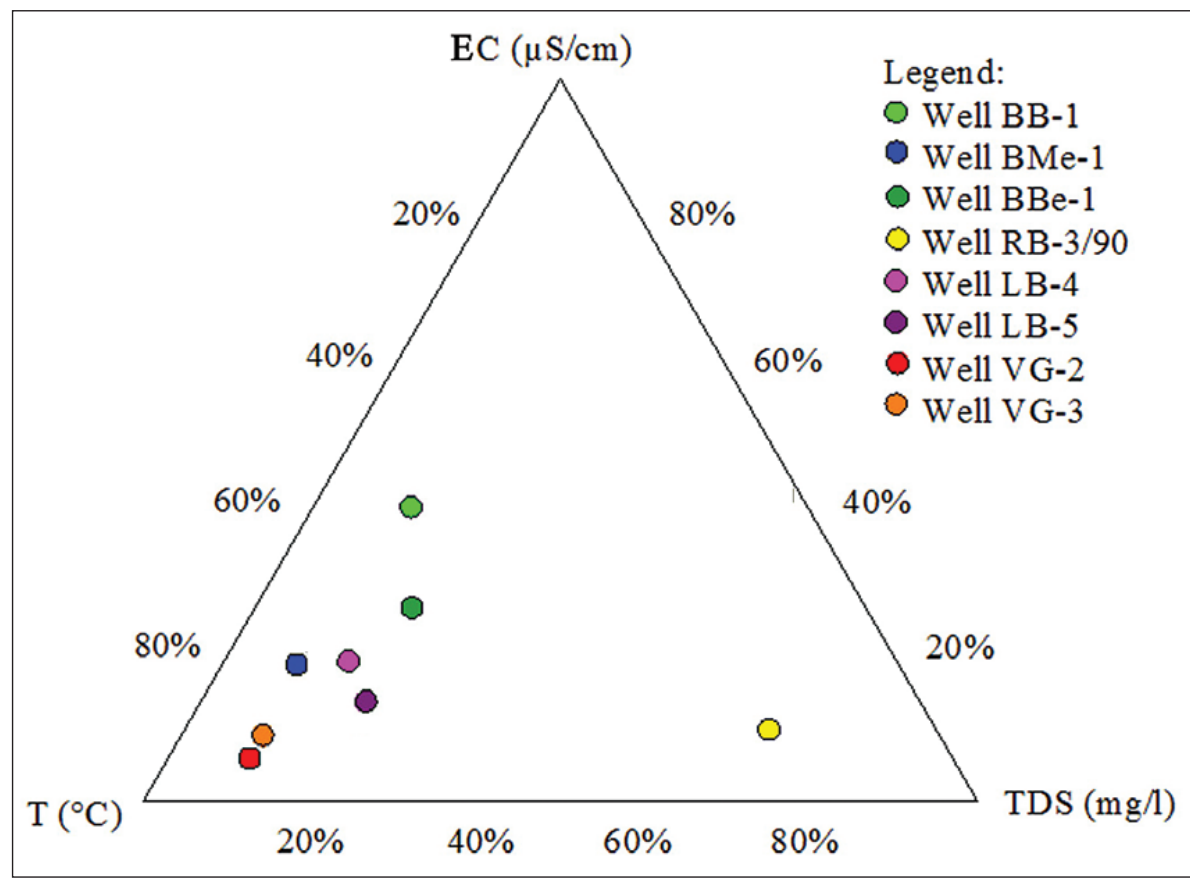

Fig. 5: Ternary diagram of temperature ( $T$ ), conductivity (EC) and total dissolved solids (TDS) of the tested mineral water samples.

Metković and Belotić $-\mathrm{Pav}=676 \mathrm{~mm}, \mathrm{~T}=11.2{ }^{\circ} \mathrm{C}$; Radaljska Banja $-\mathrm{Pav}=1136 \mathrm{~mm}, \mathrm{~T}=11.0^{\circ} \mathrm{C}$; Lukovska Banja - Pav $=607.9-1570 \mathrm{~mm}, \mathrm{~T}=10.4^{\circ} \mathrm{C}$; and Vranjska Banja $-\mathrm{Pav}=568.9 \mathrm{~mm}, \mathrm{~T}=11.3{ }^{\circ} \mathrm{C}$ (Martinović \& Milovojević 1998; Krunić 1999; Filipović 2003; Filipović et al. 2005; Martinović et al. 2012).

Biofilms at Bogatić, Metković and Belotić were sampled in December 2014, when autumn turned into winter. December 2014 was characterized by a cold autumn and severe winter. At the time of sampling, there was a snow cover around some of the wells. During the spring months of 2015, when sampling was undertaken at Radaljska Banja, Lukovska Banja and Vranjska Banja, there was a lot of rain and humidity was high.

PCA (Fig. 8) was used to illustrate the relationship between documented cyanobacterial and algal taxa and measured environmental variables. All measured environmental variables (physical and chemical water parameters, macronutrients and micronutrients) were submitted to PCA, but only those showing high correlation coefficients with the first two PCA axes were shown in the ordination diagram. It is apparent that $\mathrm{Ca}^{2+}$ and $\mathrm{Mg}^{2+}$ correlate with the positive part of the first PCA axis ( $r=0.8095$ and $r=0.8418$, respectively). Many other variables are correlated with the negative part of the first PCA axis: $\mathrm{NO}_{3}^{-}(\mathrm{r}=-0.5273), \mathrm{NO}_{2}^{-}(\mathrm{r}=-0.6342), \mathrm{SO}_{4}^{2-}$ $(\mathrm{r}=-0.5476), \mathrm{HCO}_{3}^{-}(\mathrm{r}=-0.4916), \mathrm{pH}(\mathrm{r}=-0.4297)$ and $\mathrm{T}(\mathrm{r}=-0.3404)$. H2S correlated with the negative part of the second PCA axis $(r=-0.5662)$. Chroococcales that prevailed in Vranjska Banja showed a positive correlation with increasing $\mathrm{T}$, indicating that coccoid cyanobacterial taxa are the most adaptive to high tem- peratures. They also exhibited a positive correlation with $\mathrm{pH}$, nitrogen compounds and other parameters that negatively correlated with the first PCA axis. On the other hand, Nostocales did not correlate with the measured factors (including nitrogen compounds), except for a negative correlation with $\mathrm{H}_{2} \mathrm{~S}$. The non-correlation with nitrogen compounds was expected, since Nostocales are capable of fixing nitrogen. Oscillatoriales, Chlorophyta and Bacillariophyta were negatively correlated with $\mathrm{T}$. Debnath et al. (2009) also concluded that some members of the Oscillatoriales order (i.e. Phormidium sp.) are negatively correlated with $\mathrm{T}$ and $\mathrm{pH}$.

The temperature, $\mathrm{pH}$ value in the near-well region, physical and chemical characteristics of the mineral water, and interactions of the water with the aquifer matrix have a considerable effect on the survival and growth of microorganisms, as well as on the spatial variability of the taxa identified in the mineral water ecosystem and biofilm.

Psychrophiles are microorganisms capable of growth in low-temperature environments, from $-5^{\circ} \mathrm{C}$ to $+20{ }^{\circ} \mathrm{C}$. They can even survive in colder temperatures. Mesophiles are microorganisms that grow in moderate temperatures, the optimum range being $30-45^{\circ} \mathrm{C}$. Thermophiles grow in high-temperature environments (above $45-50{ }^{\circ} \mathrm{C}$ ), whereas extremophiles survive in temperatures of $40-100{ }^{\circ} \mathrm{C}$ or higher (Jemcev \& Đukić 2000) (Fig. 9).

One of the most important factors that influence the diversity of microorganisms in thermal mats is temperature. It has been reported that microbial diversity decreases with increasing temperature (Debnath et al. 

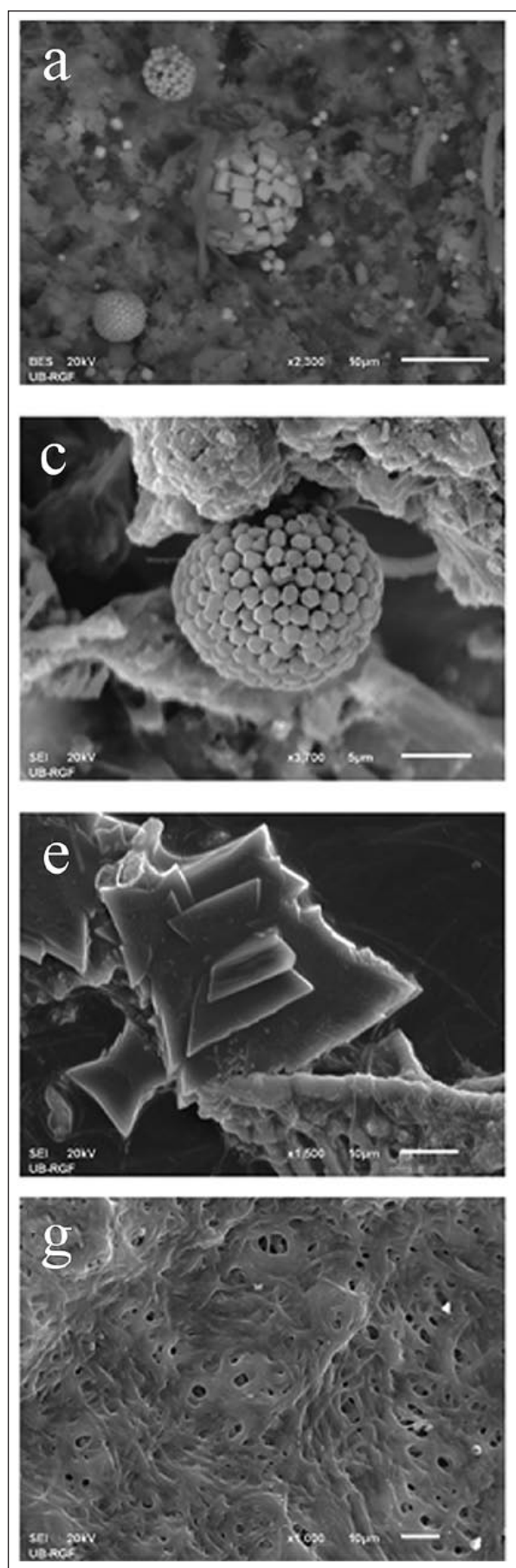
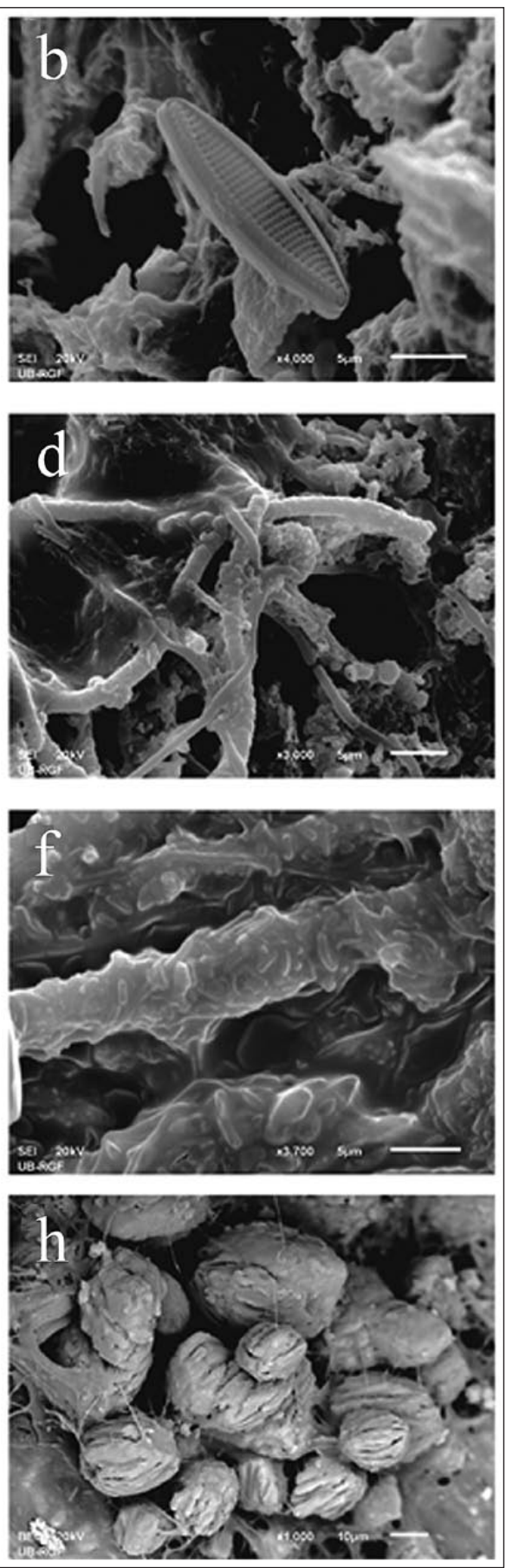

Fig. 6: SEM-EDS analysis of mat samples from Bogatić, Metković, Belotić, Lukovska, Radaljska and Vranjska Banja.

Legend: $a, c$-Colonial globular structure of framboidal pyrite; $b$ - Nitzschia spp; $d$-Pseudanabaena thermalis; $e$-Cyanobacteria covered by calcite crystals; $f$, $g$ - Cyanobacterial filaments embedded in extracellular polymeric substance (EPS); $h$ - Chroococcal cyanobacteria.

2009), such that mineral waters with temperatures over $50{ }^{\circ} \mathrm{C}$ (i.e. Bogatić, Metković, and Vranjska Banja) represent localities inhabited by specialized thermophilic species (Kaštovský \& Komárek 2001). The majority of the identified phototrophic taxa are thermophilic species (Fig. 9), but a few can also be found in other habitats (Jemcev \& Đukić 2000). All researched localities belong to the category of mineral water, with a gradation of hypo-, homeo- to hyperthermia (Fig. 9). Temperature is one of the main factors that determine the distribution and abundance of species due to its effect on enzymatic activity (Aguilera et al. 2012).

The $\mathrm{pH}$ value also has a significant effect on the growth and survival of microorganisms in the mineral water ecosystem. Mineral waters are in the $\mathrm{pH}$ range from slightly acidic to alkaline (Fig. 10a). Accordingly, the identified microorganisms are considered to be neutrophils, capable of tolerating an alkaline environ- 


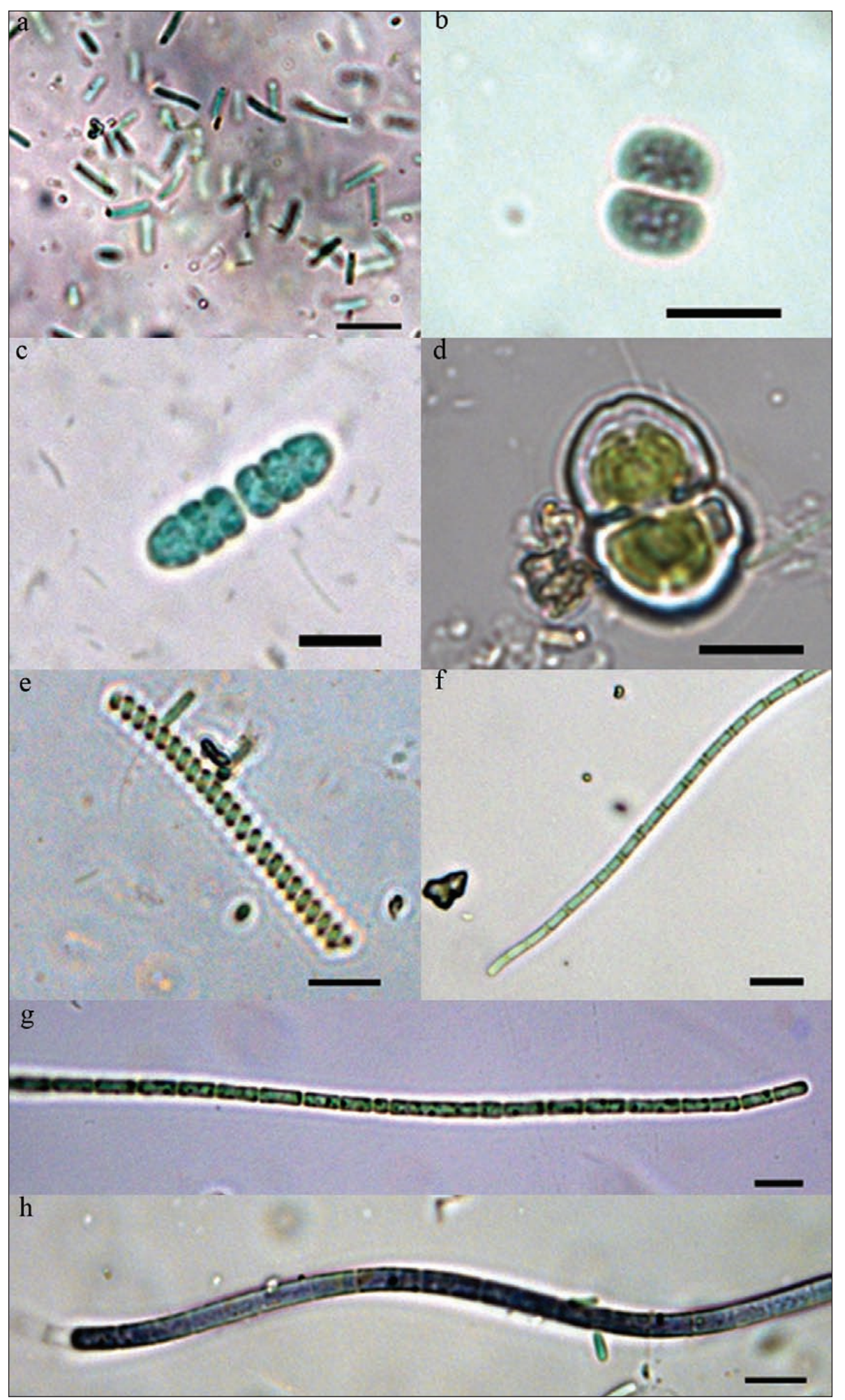

Fig. 7: Cyanobacteria and algae identified by light optical microscopy of biofilm sampled at Bogatić, Metković, Belotić, Lukovska Banja, Radaljska Banja and Vranjska Banja.

Legend: a - Synechococcus briangulatis; $b$ - Chroococcus thermalis; $c$ - Borzia trilocularis; $d$ - Cosmarium leave; e - Spirulina major; $f$ - Geitlerinema thermale; $g$ - Pseudanabaena thermalis; $h$ - Phormidium sp.; Scale bar $-10 \mu \mathrm{m}$.

ment (Fig. 10b). The survival of the identified microbial communities in the $\mathrm{pH}$ range from 6.5 to 9.5 (Radaljska Banja) is aided by their ability to adapt to surrounding extracellular conditions. In general, the microbial cyto- plasm is characterized by a neutral reaction and a large number of important cell constituents can decompose in an alkaline medium (RNA, phospholipids) (Jemcev \& Đukić, 2000). 


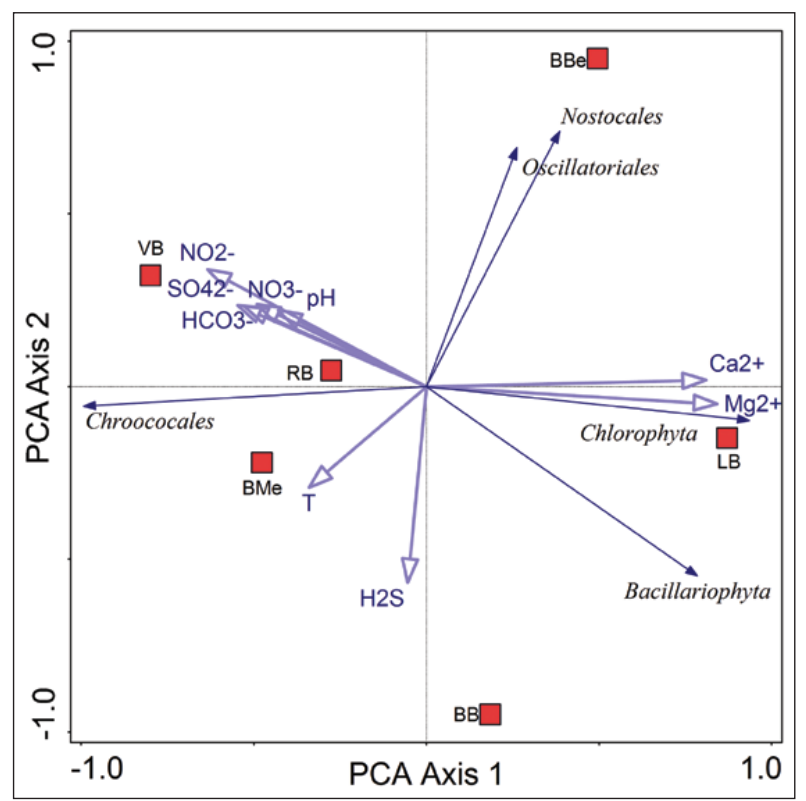

Fig. 8: PCA ordination diagram showing the relationship between cyanobacterial (Chroococcales, Oscillatoriales, Nostocales) and algal (Chlorophyta and Bacillariophyta) taxa arranged in five groups and environmental parameters $\left(\mathrm{Ca}^{2+}, \mathrm{Mg}^{2+}, \mathrm{NO}_{3}^{-}, \mathrm{NO}_{2}^{-}\right.$, $\mathrm{SO}_{4}^{2-}, \mathrm{HCO}_{3}^{-}, \mathrm{pH}$, and $\mathrm{H}_{2} \mathrm{~S}$ ). Red squares indicate the locality, included as a supplementary variable (BB - Bogatić, BBe - Belotić, $B M e$ - Metković, RB - Radaljska Banja, VB - Vranjska Banja, and LB-Lukovska Banja).

The survival of microorganisms in thermal biofilm depends on the chemical characteristics of the mineral water. Water chemistry is directly influenced by the geologic setting, given that the water acquires the properties of the rocks through which it flows, and is at the same time a consequence of subsequent interactions of water with the rock matrix in the zone of discharge. Water dissolves solid phase particles, which enter the liquid phase where microorganisms are able to use them. At certain sites there is further interaction of mineral water with compact rock and denuded material.

If the composition of the water falls below the required minimum, life functions cease and the microorganisms enter a latent (anabiotic) state and no longer reproduce (Jemcev \& Đukić 2000).

The mineral waters of Lukovska Banja and Vranjska Banja are characterized by elevated concentrations of nitrogen compounds (Tab. 2): LB-4 $-0.7 \mathrm{mg} / \mathrm{l} \mathrm{NO}_{3}$, LB- $5-0.5 \mathrm{mg} / \mathrm{l} \mathrm{NO}, \mathrm{VG}-2-2.3 \mathrm{mg} / \mathrm{l} \mathrm{NO}{ }_{3}$ and VG-3 $5.3 \mathrm{mg} / \mathrm{l} \mathrm{NO}$. This is one of the main nutrients for the development of algae and cyanobacteria. Non-heterocytous forms of cyanobacteria prefer areas that are rich in nitrogen, compared to heterocytous forms that are usually found in places with lower concentrations of this nutrient (Debnath et al. 2009). Elevated concentrations of sulfides have an adverse effect on the development of cyanobacteria and algae, since they can inhibit photosynthesis (Ferrari et al. 2002). High concentrations of this ion were recorded at mineral springs in Mačva (sampling site BB-1 - $2.5 \mathrm{mg} / \mathrm{l} \mathrm{H}_{2} \mathrm{~S}$ ) and Radaljska Banja (sampling site RB-3/90 - $2.1 \mathrm{mg} / \mathrm{l} \mathrm{H}_{2} \mathrm{~S}$ ). Heavy metals (lead, cadmium, mercury, nickel, silver) (Tab. 2) were generally detected in mineral waters at all the localities.

The hydrogeologic aspect of the research of the growth of phototrophic microorganisms in the vicinity of the points of emergence of mineral water and on wellheads is of an applicative nature. It focuses on the role in the creation of precipitates, i.e. biofouling and incrustation of well casing and wellhead. These processes, alone or in synergy, cause well ageing (Driscoll 1986; Houben \& Treskatis 2007). For example, the discharge capacity of well BB-1 at Bogatić decreased from $60 \mathrm{l} / \mathrm{s}$ at a pressure of $2.9 \mathrm{bar}$ in 1986 to $37 \mathrm{l} / \mathrm{s}$ at a pressure of $2.5 \mathrm{bar}$ in 2014, as established by a hydrodynamic test (Fig. 11). Mineral salt and alkali precipitates are formed as a resulted of a

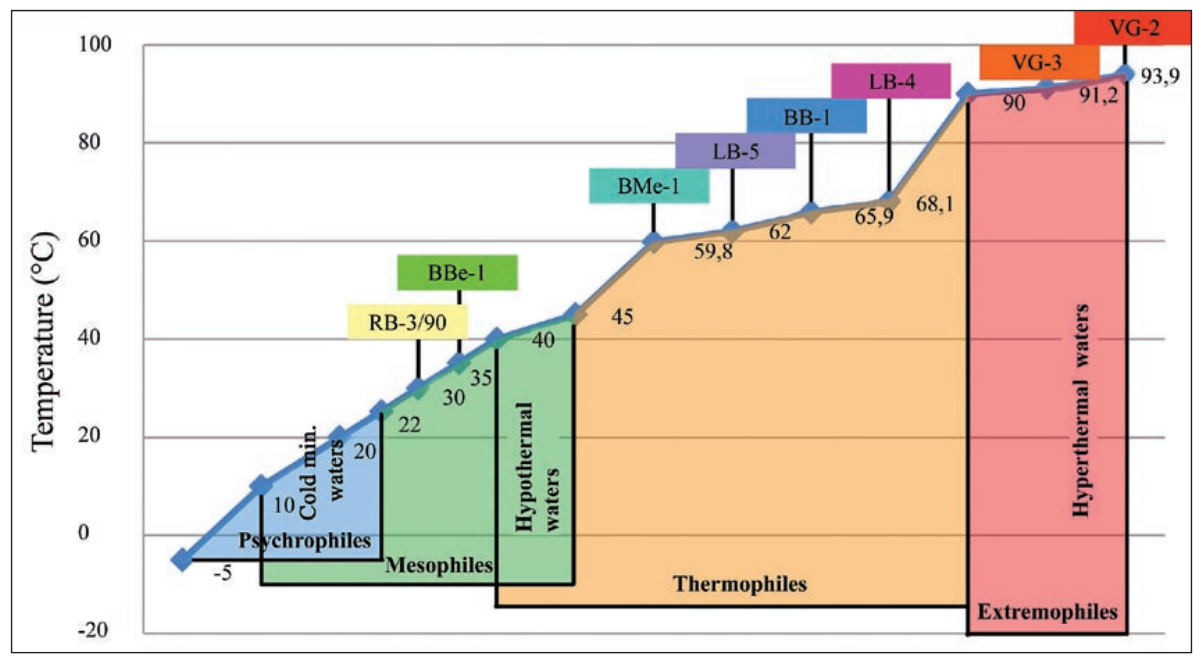

Fig. 9: Classification of mineral waters (a) and microorganisms (b) based on temperature.

Legend: BB-1- well in Bogatić; $B M e-1$ - well in Metković; BBe-1 - well in Belotić; RB-3/90 - well in Radaljska Banja; LB-4 - well in Lukovska Banja; LB-5 - well in Lukovska Banja; VG-2 - well in Vranjska Banja; VG-3 - well in Vranjska Banja. 


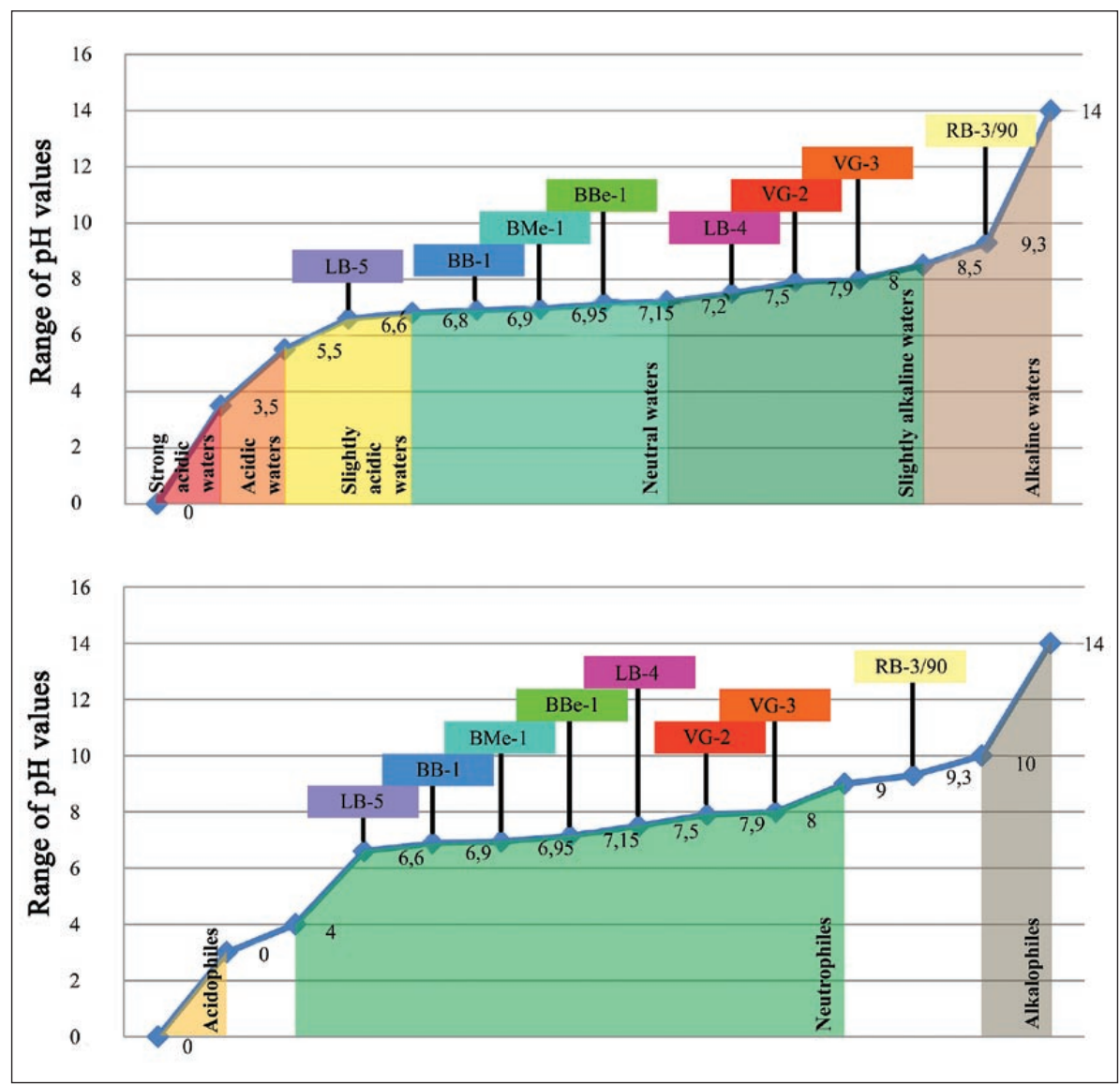

Fig. 10: Classification of mineral waters (a) and microorganisms (b) based on $\mathrm{pH}$, including categorization of wells by type of mineral water and microbial community.

Legend: BB-1- well in Bogatić; BMe-1 - well in Metković; BBe-1 - well in Belotić; RB-3/90 - well in Radaljska Banja; LB-4 - well in Lukovska Banja; LB-5 - well in Lukovska banja; VG-2 - well in Vranjska Banja; VG-3 - well in Vranjska Banja.
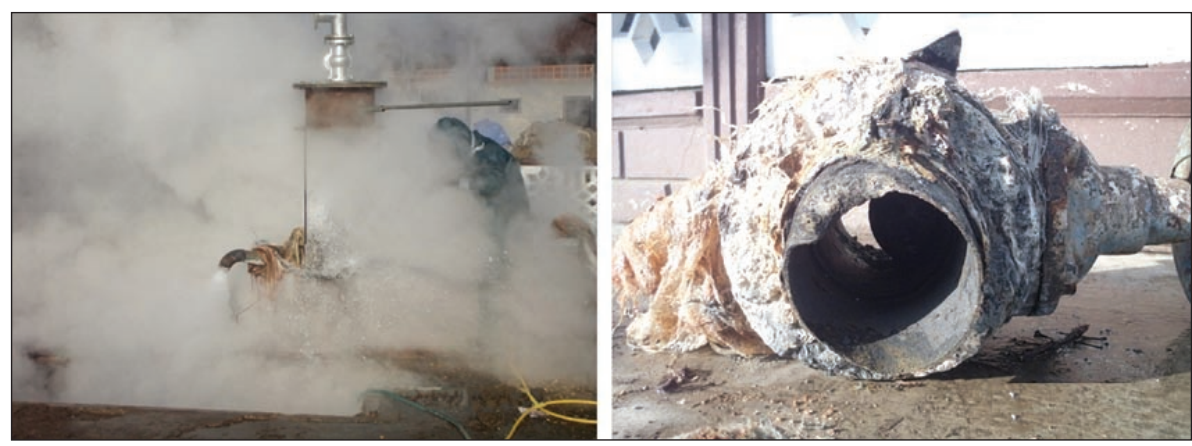

Fig. 11: Condition of well BB-1 (Photo: M. Lazić, 2014).

supersaturated solution. When the product of solubility of a potentially precipitating compound is exceeded, it becomes deposited (in this case calcium carbonate). When the pressure is sub-atmospheric, and particularly where the temperature is elevated, carbon dioxide is freed from the water. This changes the equilibrium of the solution and causes low-solubility calcium carbonate to be precipitated. The concentration of free carbon dioxide can be higher than needed to keep calcium carbonate in solution. The excess is aggressive towards limestone and will react with calcium carbonate, if in contact with it, such that precipitates on a free-flowing well are a result of a disturbed chemical equilibrium at the wellhead. The partial pressure of carbon dioxide there is 2.4 bar. When the tube of well BB-1 is fully "warmed up", the artesian pressure is estimated at 2.9 bar, and knowing that there is 0.03 bar in the air, it is obvious that carbon dioxide is freed at the wellhead and causes supersaturation of calcium carbonate in the solution and its precipitation (Papić 1991; Martinović \& Milivojević 1998).Calcium carbonate precipitation within the zone of only $15 \mathrm{~m}$ from the well was attributed to a lowered total pressure and freeing of carbon dioxide from the water, aided by elevated temperature.

At Metković, well BMe-1, built in 1987, delivered mineral water at a temperature of $63{ }^{\circ} \mathrm{C}$; there was no notable incrustation but biofilm was present at the point of discharge (Fig. 2). Incrustation and microbial pro- 

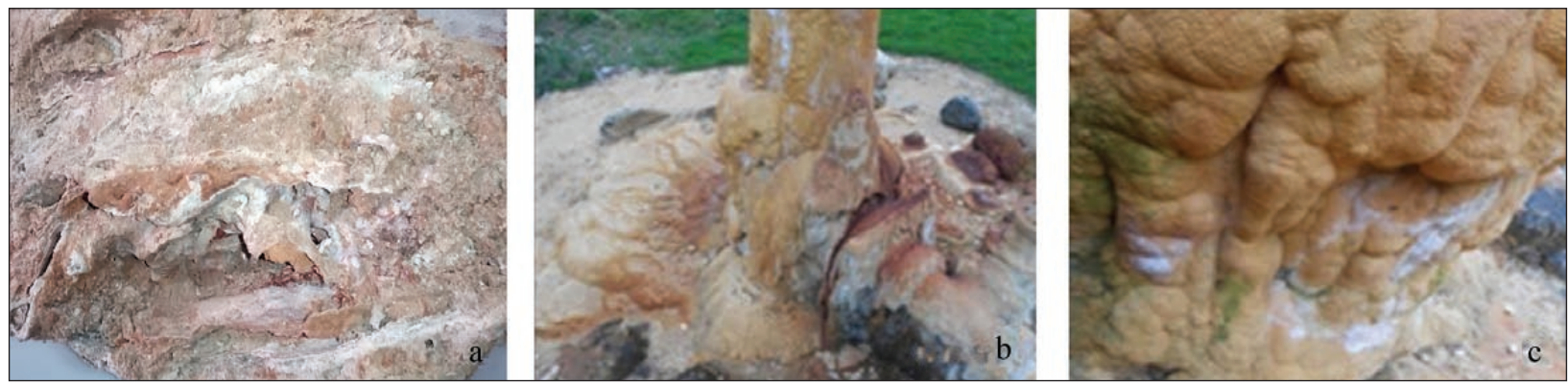

Fig. 12: Encrustation sampling points: a) well BB-1, b) well LB-4, c) well LB-5 (Photo: M. Lazić, 2014-2016).

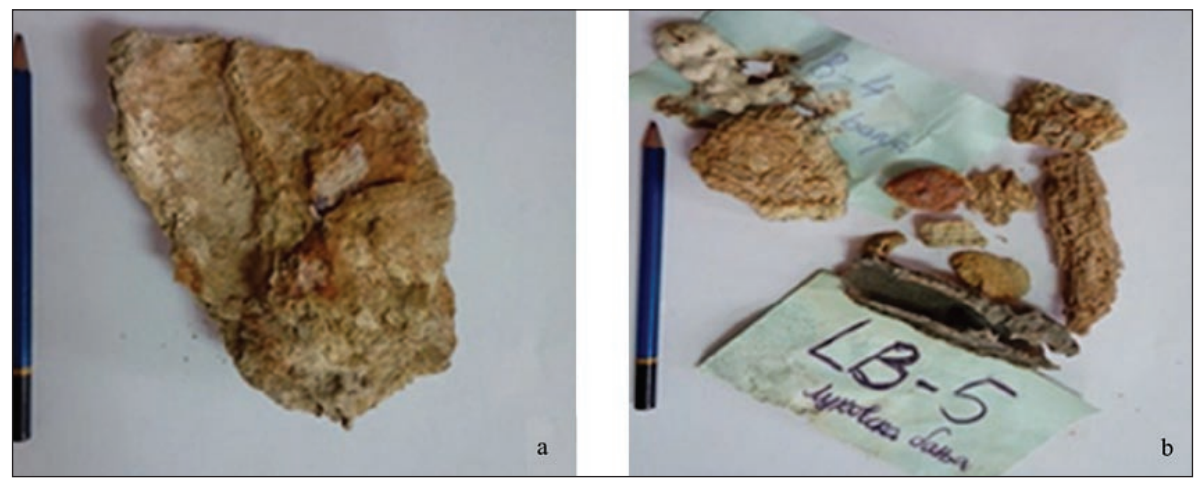

Fig. 13: Well encrustations: a) $B B-1$ at Bogatić, and b) LB-4 and LB-5 at Lukovska Banja (Photo: O. Krunić, 2016).
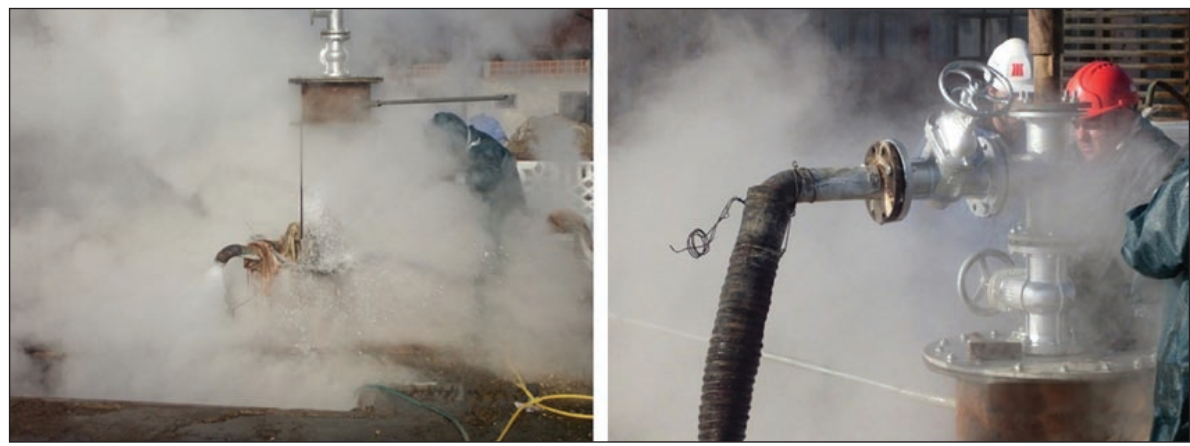

Fig. 14: Rehabilitation of well BB-1 at Bogatić (Photo: M. Lazić, 2014).

cesses (biofouling) accelerated well ageing and caused changes in the organoleptic properties and chemistry of the water.

Microorganisms rely on the mineral substrate of the mineral water for their growth and survival. To remove the outcomes of undesirable processes, wells are generally rehabilitated by a combination of mechanical, chemical and hydraulic treatments of the screen and wellhead region, with the goal of restoring the original well capacity (Fig. 14).

During the two-year study, most of the wells exhibited precipitation of calcium carbonate (Fig. 12, Fig. 13). Consequently, the high content of $\mathrm{CO}_{2}$ and $\mathrm{HCO}_{3}^{-}$resulted in the formation of precipitates. The Langelier Saturation Index (LSI) and Ryznar Stability Index (RSI) were used to determine the incrustative and corrosive properties of water. The main parameters that lead to the formation of precipitates are: partial pressure of $\mathrm{CO}_{2}$, temperature, $\mathrm{pH}$ and TDS. The Langelier Stability Index was applied to determine the propensity of water to form a calcium carbonate precipitates.

$$
\begin{gathered}
\text { SILang }=p H-p H s \\
p H s=9.92-\frac{t}{40}-\log \left[\mathrm{Ca}^{2+}\right]-\log \left[\mathrm{HCO}_{3}^{-}\right]+0.2 \log [S .0]
\end{gathered}
$$

where:

SI Lang - Langelier Stability Index,

$\mathrm{pH}$ - measure of hydrogen ion $\left(\mathrm{H}^{+}\right)$activity in solution, $\mathrm{pHs}-\mathrm{pH}$ at which the water is saturated with calcium carbonate,

$\mathrm{t}$ - groundwater temperature $\left({ }^{\circ} \mathrm{C}\right)$,

$\mathrm{Ca}^{2+}-$ calcium concentration $(\mathrm{mg} / \mathrm{l})$,

$\mathrm{HCO}_{3}^{-}$- bicarbonate concentration (mg-ekv/l),

S.O. - dry residue $(\mathrm{mg} / \mathrm{l})$. 
If: SI Lang $>0$, the water is prone to precipitation of $\mathrm{CaCO}_{3}$; SI Lang $<0$, the water is not prone to precipitation of $\mathrm{CaCO}_{3}$, it is corrosive if oxygen is dissolved in water.

The aggressiveness of water to metal surfaces was assessed on the basis of the Ryznar Stability Index (SIRyz):

SIRyz $=2 p H s-p H$

If: SIRyz $>8.5$, the water is highly aggressive towards metal; 6.8. $<$ SIRyz $<8.5$ water is aggressive towards metal; $6.2<$ SI Ryz $<6.8$ water is stable; $5.5<$ SIRyz $<6.2$ water is prone to lime precipitation; and SIRyz $<5.5$ water is highly prone to lime precipitation.

In the present case, the calculated Langelier Saturation Index (SILang) and Ryznar Stability Index (SIRyz) of the studied mineral water occurrences are shown in Tab. 4.

Tab.4: Langelier Saturation Index (SILang) and Ryznar Stability Index (SIRyz).

\begin{tabular}{l|l|l|l|l}
\hline Well & $p H$ & $p H s$ & SILang & SIRyz \\
\hline BB-1* & 6.9 & 6.2 & 0.7 & 5.5 \\
\hline BMe-1 & 6.9 & 6.2 & 0.7 & 5.5 \\
\hline BBe-1 & 7.2 & 7.3 & -0.1 & 7.5 \\
\hline RB-3/90 & 9.3 & 9.3 & 0 & 9.3 \\
\hline LB-4* & 7.5 & 6.6 & 0.9 & 5.7 \\
\hline LB-5 $^{*}$ & 6.6 & 6.4 & 0.2 & 6.2 \\
\hline VG-2* & 7.9 & 6.2 & 1.7 & 4.5 \\
\hline VG-3* & 8.0 & 6.1 & 1.9 & 4.2 \\
\hline
\end{tabular}

${ }^{*} B B-1, L B-4, L B-5, V G-2, V G-3$ - occurrences of mineral water whose temperature was higher than $60^{\circ} \mathrm{C}$.

The results presented in Tab. 4 corroborate that at a mineral water temperature above $60^{\circ} \mathrm{C}$, there was corrosion-free incrustation - namely lime precipitation (SILang $>0$, SIRyz $=5.5$ ). Consequently, the general conclusion was that corrosion of the wellhead and upper parts of the well casing was caused by the presence of free $\mathrm{CO}_{2}$ and $\mathrm{H}_{2} \mathrm{~S}$ (Tab. 2).

It is believed that microorganisms play the important role of biomineralizers in the $\mathrm{CaCO}_{3}$ precipitation process. The cyanobacterium produces $\mathrm{CaCO}_{3}$ by reducing the bicarbonate ion $\left(\mathrm{HCO}_{3}^{-}\right)$to carbonate, whereby the medium is additionally alkalized and the carbonate ion $\left(\mathrm{CO}_{3}^{2-}\right)$ created from the following reaction (Plummer et al. 1978; Buhmann \& Dreybrodt 1987; Chafetz 1994; Flügel 2004):

$\mathrm{HCO}_{3}^{-}+\mathrm{OH}^{-} \rightarrow \mathrm{CO}_{3}^{2-}+\mathrm{H}_{2} \mathrm{O}$

Given a certain percentage of the $\mathrm{Ca}^{2+}$ ion in the studied occurrences of mineral water, $\mathrm{CaCO}_{3}$ is precipi- tated on the surface of cyanobacteria according to the reaction:

$\mathrm{Ca}^{2+}+\mathrm{CO}_{3}^{2-} \rightarrow \mathrm{CaCO}_{3} \downarrow$

Although the role of microorganisms in the process of $\mathrm{CaCO}_{3}$ crystallization has not been completely understood, the biomineralization process is believed to take place at the cell wall and that extracellular macromolecules (extracellular polymeric substances - EPS) play a particularly important role in this process. Cyanobacteria can provide nucleation sites for the formation of minerals and $\mathrm{CaCO}_{3}$ precipitates, on the sheaths, where they become trapped among the trichomes. As algae grow, high $\mathrm{pH}$ values favor the precipitation of calcium carbonate that forms layers which remain stable for a long period of time (Ward et al. 2002).

\section{USE OF ALGAE IN BIOTECHNOLOGY}

Since the formation of minerals by geologic processes is a long-term process, the ability to stimulate microorganisms to create targeted biominerals is of great importance and it is possible to cultivate select algae and microorganisms from thermal ecosystems for that purpose. With the exception of calcium carbonate, many important biominerals can be obtained through biomineralization processes (i.e. carbonate oxides, sulfides, phosphates, sulfates, nitrates, and silicate halogenides) (Plummer et al. 1978; Buhmann \& Dreybrodt 1987; Chafetz 1994; Flügel 2004).

A good example of the use of thermophilic algae in biotechnology is the production of bioethanol ( $\mathrm{Li}$ et al. 2008) and the extraction of poly-hydroxybutyrate from Synechococcus spp., a compound used to degrade plastics (Mongra 2013), among other biorefinery products.

Cosmarium laeve, which has been detected in Bogatić, Belotić, and Lukovska Banja, is of special interest since it is a natural source of various bioactive molecules. Phormidium sp., for example, can produce antimicrobial compounds (Mongra 2013). Extremely thermophilic species, such are those identified in Vranjska Banja (VG-2 and VG-3), are used in biotechnology to produce vitamins, enzymes, lactic acid and other substances important in agriculture and medicine.

Also, Spirulina is a rich source of vitamins (A, C, $\mathrm{D}, \mathrm{E}$ and $\mathrm{B}$ ), minerals, fiber, beta-carotene, protein, and minerals (iron, potassium, magnesium, sodium, phosphorus, zinc and selenium). It has a positive effect on the immune and nervous systems, brain and eyes, protects the body from harmful substances, helps reduce weight, and decreases the risk of cancer, all owing to a powerful antioxidant - zeaxanthin. It also has anti-inflammatory and anti-allergic properties and helps relieve stress and depression (Hoseini et al. 2013; Šaraba \& Krunić 2017). 


\section{CONCLUSIONS}

The studied points of emergence of mineral water and wellheads in Serbia (Bogatić, Metković and Belotić in the Mačva District, as well as Radaljska Banja, Lukovska Banja and Vranjska Banja) were found to be favorable habitats for various groups of microorganisms. The results served as a basis for drawing general conclusions about the biodiversity and geoenvironment, given that mineral waters are extracted from karst, fractured and intergranular aquifers of different lithologies and geologic age. The water types were $\mathrm{HCO}_{3}^{-}-\mathrm{Na}^{+}+\mathrm{K}^{+}$and $\mathrm{SO}_{4}^{2-}$, $\mathrm{HCO}_{3}^{-}-\mathrm{Na}^{+}+\mathrm{K}^{+}$, and the temperature range from 30 to $93.9^{\circ} \mathrm{C}$.

The mineral waters extracted from igneous rocks exhibited the largest number of phototrophic microbial taxa: 15 species were found at Radaljska Banja and 12 in Vranjska Banja. There were ten phototrophic microbial taxa each in the karst aquifers within Triassic limestones and dolomites at Bogatić and Belotić, and nine taxa in the Neogene fractured sandstone aquifer at Metković. In Lukovska Banja, the mineral water is formed in sedimentary and metamorphic rocks (Cretaceous limestones, serpentinites, cherts), with occasional diabase interbeds, where the smallest number of phototrophic microbial taxa were noted (only eight). Given that sampling was conducted at the ground surface, apart from the chemical composition of the water, microclimate played an important role.

The research revealed representatives of three groups of phototrophic microorganisms: Cyanobacteria, Chlorophyta and Bacillariophyta. Cyanobacteria were the most numerous and dominated by the order Oscillatoriales, followed by representatives of the phylums Bacillariophyta and Chlorophyta.

Phototrophic biofilms near points of emergence of mineral waters and at wellheads in Serbia had not been examined in the past. The present study, apart from addressing the rehabilitation of biofouled wellheads by mechanical, chemical and hydraulic treatments at Bogatić, is significant because it provides an assessment of the biodiversity of mineral waters in Serbia.

The general conclusion was that mineral water occurrences favor the development of unique microbial communities, which deserve special attention from the perspective of protecting the environment and genetic pool. Hence, protection of mineral waters is recommended to conserve biodiversity.

\section{ACKNOWLEDGEMENT}

The Serbian Ministry of Science has financially supported this research under contracts TR33053 and OI176020.

\section{REFERENCES}

Aguilera, A., Souza-Egipsy, V. \& R. Amils, 2012: Photosynthesis in extreme environments.- In: Najafpour, M. (ed.) Artificial Photosynthesis. InTech, pp. 271-288, Rijeka.

Beech, I.B. \& J.A. Sunner, 2006: Biocorrosion in drinking water distribution systems.- In: Newcombe, G. \& D. Dixon (eds.) Interface Science in Drinking Water Treatment Theory and Application, vol. 10. Interface Science and Technology, Academic Press, pp. 245-255, Amsterdam.
Buhmann, D. \& W. Dreybrodt, 1987: Calcite dissolution kinetics in the system $\mathrm{H}_{2} \mathrm{O}-\mathrm{CO}_{2}-\mathrm{CaCO}_{3}$ with the participation of foreign ions.- Chemical Geology, 64, 1-2, 89-102. DOI: https://doi.org/10.1016/00092541(87)90154-9.

Chafetz, H. S., 1994: Bacterially induced precipitates of calcium carbonate and lithification in microbial mats.- In: Krumbein, W.E. et al. (eds.) Biostabilization of sediments. Oldenburg Press, pp. 149-164, Oldenburg. 
Cvijan, M., 2013: Algologija.- University of Belgrade, Faculty of Biology, pp. 196, Belgrade.

Debnath, M., Mandal, N.C. \& S. Ray, 2009: The study of cyanobacterial flora from geothermal springs of Bakreswar, West Bengal, India.- Algae, 24, 4, 185-193. DOI: https://doi.org/10.4490/ ALGAE.2009.24.4.185.

Des Marais, D.J., 1995: The biogeochemistry of hypersaline microbial mats.- In: Jones, J.G. et al. (eds.) Advances in Microbial Ecology. Springer, pp. 251-274, Boston. DOI: https://doi.org/10.1007/978-1-46847724-5_6.

Des Marais, D.J., 2000: When did photosynthesis emerge on Earth.- Science, 289, 5485, 1703-1705. DOI: 10.1126/science.289.5485.1703.

Donlan, R.M., 2002: Biofilms: microbial life on surfaces.Emerging Infectious Diseases, 8, 9, 881-890. DOI: https://dx.doi.org/10.3201/eid0809.020063.

Driscoll, F.G., 1986: Groundwater and Wells (2 $2^{\text {nd }}$ ed.).Johnson Filtration Systems Inc., pp. 1089, St. Paul.

Dragišić, V. \& D. Polomčić, 2009: Hidrogeološki rečnik.University of Belgrade, Faculty of Mining and Geology, pp. 572, Belgrade.

Farmer, J.D., 2000: Hydrothermal systems: doorways to early biosphere evolution.- GSA Today 10, 7, 1-9.

Ferrari, S.G., Italiano, M.C. \& H.J. Silva, 2002: Effect of a cyanobacterial community on calcium carbonate precipitation in Puente del Inca (Mendoza, Argentina).- Acta Botanica Croatica, 61, 1, 1-9.

Filipović, B. 2003: Mineralne, termalne i termomineralne vode Srbije.- University of Belgrade, Faculty of Mining and Geology, pp. 278, Belgrade.

Filipović, B., Krunić, O. \& M. Lazić, 2005: Regionalna hidrogeologija Srbije.- University of Belgrade, Faculty of Mining and Geology, pp. 401, Belgrade.

Flügel, E., 2004: Microfacies of Carbonate Rocks.- Springer Berlin Heidelberg, pp. 976, New York. DOI: https:// doi.org/10.1007/978-3-662-08726-8.

Griebler, C., Mindl, B. \& D. Slezak, 2001: Combining DAPI and SYBR Green II for the enumeration of total bacterial numbers in aquatic sediments.- International Review of Hydrobiology, 86, 4-5, 453-465. DOI: https://doi.org/10.1002/1522-2632(200107)86:4/5<453::AID-IROH453>3.0.CO;2-L.

Griebler, C. \& T. Lueders, 2009: Microbial biodiversity in groundwater ecosystems.-Freshwater Biology, 54, 4, 649-677. DOI: https://doi.org/10.1111/j.1365-2427 .2008.02013.x

Hazen, T.C., Jiménez, L., López de Victoria, G. \& C.B. Fliermans, 1991: Comparasion of bacterial from deep subsurface sediment and adjacent groundwater. Microbial Ecology, 22, 1, 293-304. DOI: https://doi. org/10.1007/BF02540231.
Hofmann, H.J., Grey, K., Hickman, A.H. \& R.I. Thorpe, 1999: Origin of $3.45 \mathrm{Ga}$ coniform stromatolites in Warrawoona group, Western Australia.- Geological Society of America Bulletin, 111, 8, 12561262. DOI: http://dx.doi.org/10.1130/0016-7606(1999) $111<1256$ :OOGCSI>2.3.CO;2.

Hofmann, G.E., Blanchette, C.A., Rivest, E.B. \& L. Kapsenberg, 2013: Taking the pulse of marine ecosystems: The importance of coupling long-term physical and biological observations in the context of global change biology.- Journal of Oceanography, 26, 3, 140-148. DOI: https://doi.org/10.5670/ oceanog.2013.56.

Hoseini, S.M., Khosravi-Darani, K. \& M.R. Mozafari, 2013: Nutritional and Medical Applications of Spirulina Microalgae.- Mini Reviews in Medicinal Chemistry, 13, 8, 1231-1237. DOI: https://doi.org/1 $0.2174 / 1389557511313080009$.

Houben, G. \& C. Treskatis, 2007: Water Well Rehabilitation and Reconstruction.- McGraw-Hill Education, pp. 391, New York.

Jemcev, V. \& D. Đukić, 2000: Mikrobiologija.- Vojnoizdavački zavod, pp. 759, Belgrade.

Kasting, J.F. \& M.T. Howard, 2006: Atmospheric composition and climate on the early Earth.- Philosophical Transactions of the Royal Society B: Biological Sciences, 361, 1474, 1733-1742. DOI: 10.1098/ rstb.2006.1902.

Kaštovský, J. \& J. Komárek, 2001: The phototrophic micro vegetation of seminatural thermal springs in Karlovy Vary.- Biologická fakulta Jihočeské univerzity, Czech Republic.

Komárek, J., 2013: Cyanoprokaryota. 3. Teil: Heterocystous Genera.- Süsswasserflora von Mitteleuropa 19/3, Springer Spektrum, pp. 1131, Heidelberg.

Komárek, J. \& K. Anagnostidis, 2005: Cyanoprokaryota. 2. Teil: Oscillatoriales.- Süsswasserflora von Mitteleuropa 19/2, Springer Spektrum, pp. 759, Berlin.

Komárek, J. \& K. Anagnostidis, 1998: Cyanoprokaryota. 1. Teil: Chroococcales.- Süsswasserflora von Mitteleuropa 19/1, Springer Spektrum, pp. 548, Berlin.

Komárek, J. \& B. Fott, 1983: Chlorophyceae (Grünalgen), Ordnung Chlorococcales.- Nordic Journal of Botany, 5, 1, 111. DOI: https://doi.org/10.1111/j.17561051.1985.tb02080.x.

Komárek, J., Kaštovský, J., Mareš, J. \& J.R. Johansen, 2014: Taxonomic classification of cyanoprokaryotes (cyanobacterial genera) 2014, using a polyphasic approach.- Preslia, 86, 295-335.

Krieger, W. \& J. Gerloff, 1965: Die Gattung Cosmarium.Cramer Verlag, pp. 410, Weinheim. 
Krunić, O. 1999: Termomineralne vode Srbije - osnovni tipovi i karakteristike.- PhD thesis. University of Belgrade, Faculty of Mining and Geology, Belgrade.

Krunić, O., 2012: Mineralne vode.- University of Belgrade, Faculty of Mining and Geology, Belgrade.

Krunić, O., Subakov-Simić, G., Popović, S., Lazić, M., Kljajić, Ž. \& V. Šaraba, 2016: Hidrogeobiologija fototrofnih mikroorganizama u biofilmovima odabranih pojava termomineralnih voda Srbije.- In: Vranješ, A., Vukićević, M. \& S. Drobac (eds.) XV srpski simpozijum o hidrogeologiji sa međunarodnim učešćem, 14 ${ }^{\text {th }}-17^{\text {th }}$ September 2016, Kopaonik. University of Belgrade, Faculty of Mining and Geology, 351-356, Belgrade.

Lange-Bertalot, H., Hofmann, G. \& M. Werum, 2011: Diatomeen im Süßwasser - Benthos von Mitteleuropa: Bestimmungsflora Kieselalgen für die ökologische Praxis.- Koeltz Scientific Books, pp. 908, Germany.

Lawrence, J.R. \& E.D. Caldwell, 1987: Behavior of bacterial stream populations within the hydrodynamic boundary layers of surface microenvironments. Microbial Ecology, 14, 1, 15-27. DOI: https://doi. org/10.1007/BF02011567

Lazić, M., 2003: Istražno bušenje u hidrogeologiji.- University of Belgrade, Faculty of Mining and Geology, pp. 390, Belgrade.

LeChevallier, M.W., Welch, N.J. \& D.B. Smith, 1996: Fullscale studies of factors related to coliform regrowth in drinking water.- Applied and Environmental Microbiology, 62, 7, 2201-2211.

Lehman, R.M., Colwell, F.S. \& G.A. Bala, 2001: Attached and unatthached microbial communities in a simulated basalt aquifer under fracture- and porous-flow conditions.- Applied and Environmental Microbiology, 67, 6, 2799-2809. DOI: https://doi.org/10.1128/ AEM.67.6.2799-2809.2001

Li, B. \& B.E. Logan, 2004: Bacterial adhesion to glass and metal-oxid surfaces.- Colloids and Surfaces B: Biointerfaces, 36, 2, 81-90. DOI: https:/doi. org/10.1016/j.colsurfb.2004.05.006

Li, Q., Du, W. \& D. Liu, 2008: Perspectives of microbial oils for biodiesel production.-Applied Microbiology and Biotechnology, 80, 5, 749-756. DOI: https:// doi.org/10.1007/s00253-008-1625-9

Martinović, M. \& M. Milivojević, 1998: The hydrogeothermal system of Mačva and Semberija.- In: Bussmann, W. (ed.) Geothermie: Forshung-Entwicklung-Markt: Tagungsband, 5. Geothermische Fachtagung, $12^{\text {th }}-15^{\text {th }}$ May 1998, Straubing. Straubing, 133-141, Straubing.
Martinović, M., Magazinović, S., Dimitrijević, D. \& D. Đurđanović, 2012: Mogućnost proizvodnje električne energije iz hidrogeotermalnih resursa na području surduličkog granitoidnog masiva.- In: Savić, N. \& M. Jovanović (eds.) XIV srpski simpozijum o hidrogeologiji sa međunarodnim učešćem, $14^{\text {th }}-17^{\text {th }}$ May 2012, Zlatibor. University of Belgrade, Faculty of Mining and Geology, 203-209, Belgrade.

Mongra, A.C., 2013: Cyanobacteria - potential producers of economical and medical important products in hot water spring Tattapani Himachal Pradesh.IJRRPAS, 3, 6, 910-934.

Noffke, N., Eriksson, K.A., Hazen, R.M. \& E.L. Simpson, 2006: A new window into Early Archean life: Microbial mats in Earth's oldest siliciclastic tidal deposits (3.2 Ga Moodies Group, South Africa).- Geology, 34, 4, 253-256. DOI: https://doi.org/10.1130/ G22246.1

Norton, C.D. \& M.W. LeChevallier, 2000: A pilot study of bacteriological population changes through potable water treatment and distribution.- Applied and Environmental Microbiology, 66, 1, 268-276. DOI: 10.1128/AEM.66.1.268-276.2000

Papić, P., 1991: Scaling and corrosion potential of selected geothermal water in Serbia.- UNU Geothermal Training Programme, Report 9, pp. 47, Reykjavik.

Pedersen, K., 2000: Exploration of deep intraterrestrial microbial life: current perspectives.-FEMS Microbiology Letters, 185, 1, 9-16. DOI: 10.1111/ j.1574-6968.2000.tb09033.x

Plummer, L.N., Wigley, T.M.L. \& D.L. Parkhurst, 1978: The kinetics of calcite dissolution in $\mathrm{CO}_{2}-$ water system at 5 degrees to 60 degrees $\mathrm{C}$ and 0.0 to $1.0 \mathrm{~atm}$. $\mathrm{CO}_{2}$ - $^{-}$American Journal of Science, 278, 2, 179-216. DOI: https://doi.org/10.2475/ ajs.278.2.179

Schnieders, J.H., 2003: Chemical cleaning, disinfection and decontamination of water wells.- Johnson Screens, pp. 227, St. Paul.

Schoenen, D., 1986: Microbial growth due to materials used in drinking water systems.- Journal of Biotechnology, 8, 627-647.

Schopf, J.W., 2006: Fossil evidence of Archaean life.Philosophical Transactions of the Royal Society B: Biological Sciences, 361, 1470, 869-885. DOI: 10.1098/rstb.2006.1834

Szewzyk, U. \& B. Schink, 1988: Degradation of hydroquinone, gentisate and benzoate by a fermenting bacterium in pure or defined mixed culture.- Archives of Microbiology, 151, 6, 541-545. https:/doi. org/10.1007/BF00454872 
Šaraba, V. \& O. Krunić, 2017: Geomedicinski značaj fototrofnih biofilmova na mestima isticanja odabranih pojava termomineralnih voda Srbije.- In: Komatina, S. \& N.Č. Bojat (eds.) The $7^{\text {th }}$ International Congress, Biomedicine and Geosciences - influence of environment on human health, $24^{\text {th }}-26^{\text {th }}$ May 2017, Belgrade. AGES, 155-164, Belgrade.

Ter Braak, C.J.F. \& P. Šmilauer, 2012: Canoco reference manual and user's guide: software for ordination (version 5.0).- Microcomputer Power, pp. 496, Ithaca, USA.

Tice, M.M. \& D.R. Lowe, 2004: Photosynthetic microbial mats in the 3,416-Myr-old ocean.- Nature, 431, 7008, 549-552. DOI: https://doi.org/10.1038/nature 02888
Toporski, J., Steele, A., McKay, D.S. \& F. Westall, 2003: Bacterial biofilms in astrobiology: the importance of life detection.- In: Krumbein, W.E., Paterson, D.M. \& G.A. Zavarzin (eds.) Fossil and Recent Biofilms - A Natural History of Life on Earth. Kluwer, pp. 430-445, Boston.

Visscher, P.T. \& F.J. Stolz, 2005: Microbial mats as bioreactors: populations, processes and products.- Palaeogeography, Palaeoclimatology, Palaeoecology, 219, 1-2, 87-100. DOI: https://doi.org/10.1016/j. palaeo.2004.10.016

Ward, D.M., Castenholz, R.W. \& S.R. Miller, 2002: Cyanobacteria in Geothermal Habitats.- In: Whitton, B.A. (ed.) Ecology of Cyanobacteria II. Springer, pp. 39-63, Berlin. 